\title{
ДИНАМИКА РОСТА ЭКСТРУЗИВНОГО КУПОЛА И ВАРИАЦИИ ХИМИЧЕСКОГО И МИНЕРАЛОГИЧЕСКОГО СОСТАВОВ АНДЕЗИТОВ ВУЛКАНА МОЛОДОЙ ШИВЕЛУЧ В 2001-2013 гГ.
}

\author{
(C) 2016 г. Н. В. Горбач ${ }^{1}$, М. В. Портнягин ${ }^{2,3}$, Т. М. Философова ${ }^{1}$ \\ ${ }^{1}$ Институт вулканологии и сейсмологии ДВО РАН \\ 683006 Петропавловск-Камчатский, бульвар Пийпа, 9 \\ ${ }^{2}$ Институт геохимии и аналитической химии РАН \\ 119334 Москва, ул. Косыгина, 19 \\ ${ }^{3}$ Helmholtz Centre for Ocean Research Kiel, GEOMAR, г. Kuль, ФРГ \\ e-mail: $n \_g o r b a c h @ m a i l . r u$ \\ Поступила в редакцию 29.02.2016 г.
}

\begin{abstract}
Рассмотрены особенности роста экструзивного купола вулкана Молодой Шивелуч в 2001-2013 гг. и проанализированы вариации химического и минералогического составов изверженных продуктов, соответствующих этому периоду. Показано, что по сравнению с лавами ранних этапов роста купола в 1980-1981 и 1993-1995 гг., андезиты, изверженные в 2000-х гг., менее однородны по валовому составу, содержанию кристаллов и содержат гетерогенные по составу и условиям кристаллизации вкрапленники. Такие особенности состава пород интерпретированы как следствие конвекции в малоглубинной магматической камере, вызванной поступлением новой порции глубинной магмы.
\end{abstract}

DOI: $10.7868 / \mathrm{S} 0203030616060031$

\section{ВВЕДЕНИЕ}

Шивелуч - один из наиболее активных вулканических центров Камчатки, продуктивность которого на порядок превышает аналогичные параметры для типичного островодужного вулкана [Мелекесцев и др., 1991]. Преобладающими типами его голоценовой и современной активности, которая связана с эруптивным центром Молодой Шивелуч (рис. 1), являются мощные плинианские извержения, рост экструзивных куполов и образование крупных обломочных лавин. Последнее катастрофическое извержение с образованием обломочной лавины и последующим выносом ювенильной пирокластики в виде тефры и пемзовых пирокластических потоков произошло 12 ноября 1964 г. [Белоусов, Белоусова, 1995; Горшков, Дубик, 1969; и др.].

С 1980 г. активность вулкана связана с ростом экструзивного купола в кратере извержения 1964 г. В первые два десятилетия формирование купола было связано с двумя отдельными импульсами поступления экструзивной лавы в 1980-1981 гг. и 1993-1995 гг. Эти импульсы были разделены периодом умеренной фумарольной деятельности и редких пепловых выбросов, несколько участившихся к началу 1990-ых годов [Жаринов и др., 1995]. В апреле 1993 г. после резкого увеличения скорости роста экструзии последовало первое мощное эксплозивное извержение с формированием пирокластических потоков и лахаров [Хубуная и др., 1995]. С 2001 по 2013 гг. произошло уже пять пароксизмальных эксплозивных извержений - в мае 2001 и мае 2004 гг., феврале и сентябpe 2005 г. и в октябре 2010 г. Во время этих извержений формировались протяженные пирокластические потоки, отложения которых заполняли долины рек на южном подножии вулкана. Кроме перечисленных извержений происходили и более умеренные по силе эксплозивные извержения, иногда с формированием небольших по объему пирокластических потоков. Такие события имели место в 2007-2009 и 2013 гг. В последнее десятилетие экструзивная лава поступает на поверхность практически непрерывно, а морфология купола меняется очень динамично (рис. 2).

В данной работе приведен обзор основных этапов роста экструзивного купола в кратере извержения 1964 г. и выполнена приближенная оценка объема пирокластических и экструзивных пород, изверженных в 2001-2013 гг. Показано, что этот период отличается увеличением общего расхода магмы и ростом числа эксплозивных событий по сравнению с ранними этапами формирования экструзии. Особенности динамики роста купола, а также состава лав и породообразующих минералов свидетельствуют об усилении поступления глу- 


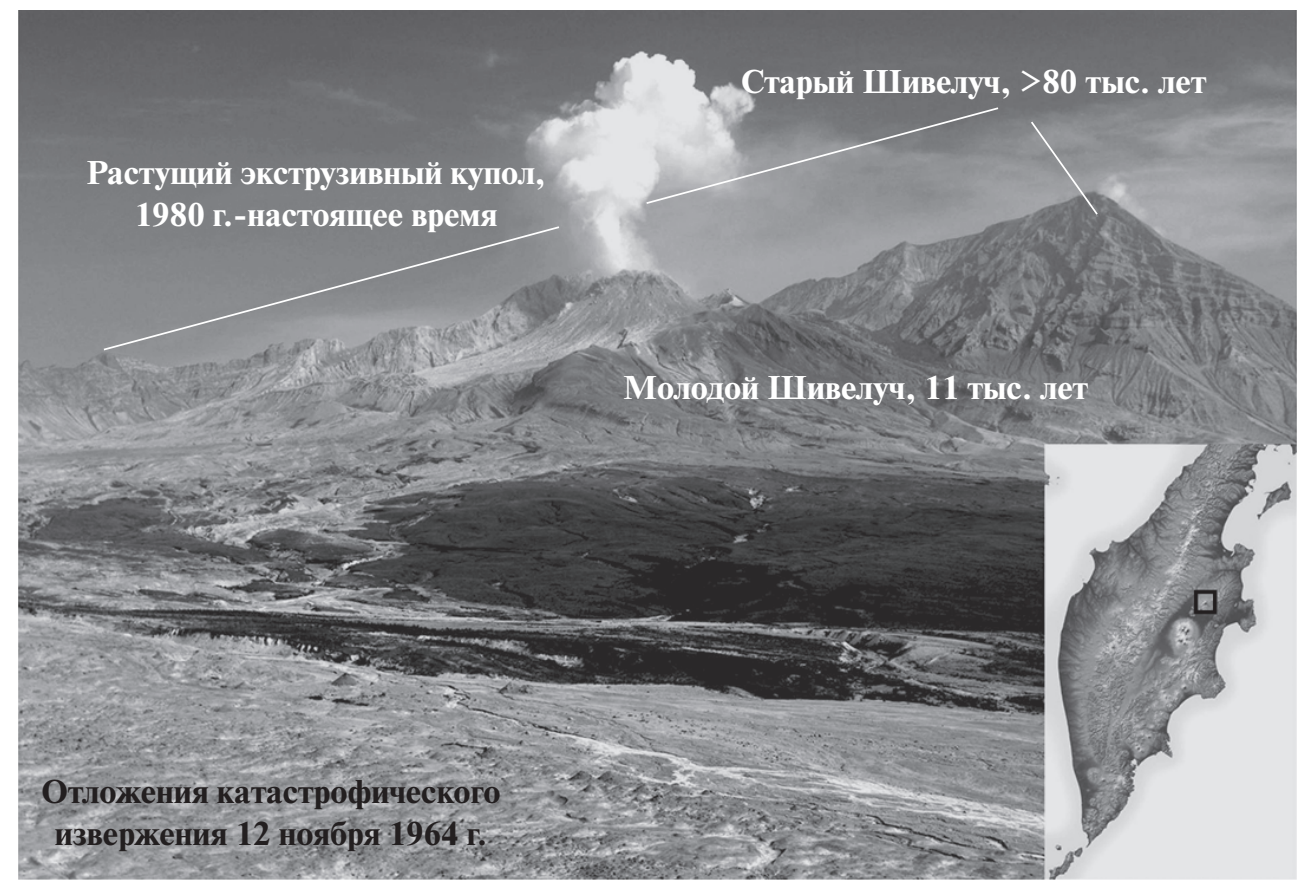

Рис. 1. Вулканический массив Шивелуч, вид с юго-востока. Фото И.В. Далецкой, июль 2007 г.

бинной магмы и процессах конвекции в малоглубинной магматической камере под вулканом.

\section{ОСНОВНЫЕ ЭТАПЫ РОСТА ЭКСТРУЗИВНОГО КУПОЛа}

Отдельные этапы роста экструзивного купола и крупнейшие эксплозивные извержения, сопровождающие этот процесс, описаны в ряде работ. Основные данные из опубликованных работ суммированы в таблице 1 и дополнены некоторыми полевыми наблюдениями, выполненными в период с 2003 по 2013 гг.

1980-1981 гг. - начало роста купола. Первые порции экструзивных лав в центральной части кратера извержения 1964 г. появились в августе 1980 г. Начало роста купола не сопровождалось ни сейсмической, ни активной эксплозивной деятельностью [Иванов и др., 1981]. Наиболее интенсивный рост экструзии наблюдался в первые два месяца извержения - к концу октября купол достиг высоты 100-120 м при диаметре основания около 350 м [Иванов и др., 1981]. По данным [Двигало, 1984], скорость поступления экструзивной лавы в этот период оценивается в $2.15 \mathrm{~m}^{3} / \mathrm{c}$. В это время купол имел классическую морфологию и структуру. В нем четко выделялась корона, сложенная крупными экструзивными блоками и обелисками, и рыхлая, осыпная агломератовая мантия [Иванов и др., 1981]. Рост купола продолжился до конца 1981 г., объем экструзии к этому времени составил $0.02 \mathrm{Kм}^{3}$ [Двигало, 1984].
В 1982 г. экструзивный процесс приостановился и на куполе отмечалась умеренная фумарольная деятельность и преобладали процессы разрушения [Жаринов и др., 1995]. В 1984-1986 гг. фумарольная деятельность дополнилась отдельными пепловыми выбросами (три взрыва за год). В 1988-1990 гг. было отмечено усиление эксплозивной активности до нескольких десятков пепловых выбросов в год, увеличение сейсмической активности и появление вулканического дрожания [Жаринов и др., 1995].

1993-1995 гг. - новый импульс роста купола. С января 1993 г. на вулкане стали фиксироваться рои землетрясений с глубиной очагов $3-5$ км и спазматическое вулканическое дрожание, интенсивность которого возросла в первой половине апреля [Горельчик и др., 1995]. В начале апреля усилился экструзивный процесс, а 21 апреля произошло эксплозивное извержение с подъемом эруптивной колонны до 15-18 км н.у.м. и формированием пирокластических и грязевых потоков [Хубуная и др., 1995; Федотов и др., 1995]. В маеиюне 1993 г. наблюдалась максимальная скорость роста экструзии (до $10-14 \mathrm{~m}^{3} / \mathrm{c}$ ), в последующие месяцы интенсивность экструзивного процесса постепенно снижалась (средняя скорость $3 \mathrm{~m}^{3} / \mathrm{c}$ ) и к началу 1995 гг. рост купола прекратился [Mелекесцев и др., 2004; Федотов и др., 2001; Dirksen et al., 2006]. Суммарный объем экструзии к началу 1995 г. оценивается в $0.2 \mathrm{kM}^{3}$, при этом $0.179 \mathrm{KM}^{3}$ поступило в ходе извержения 1993-1994 гг. [Mелекесцев и др., 2004]. 

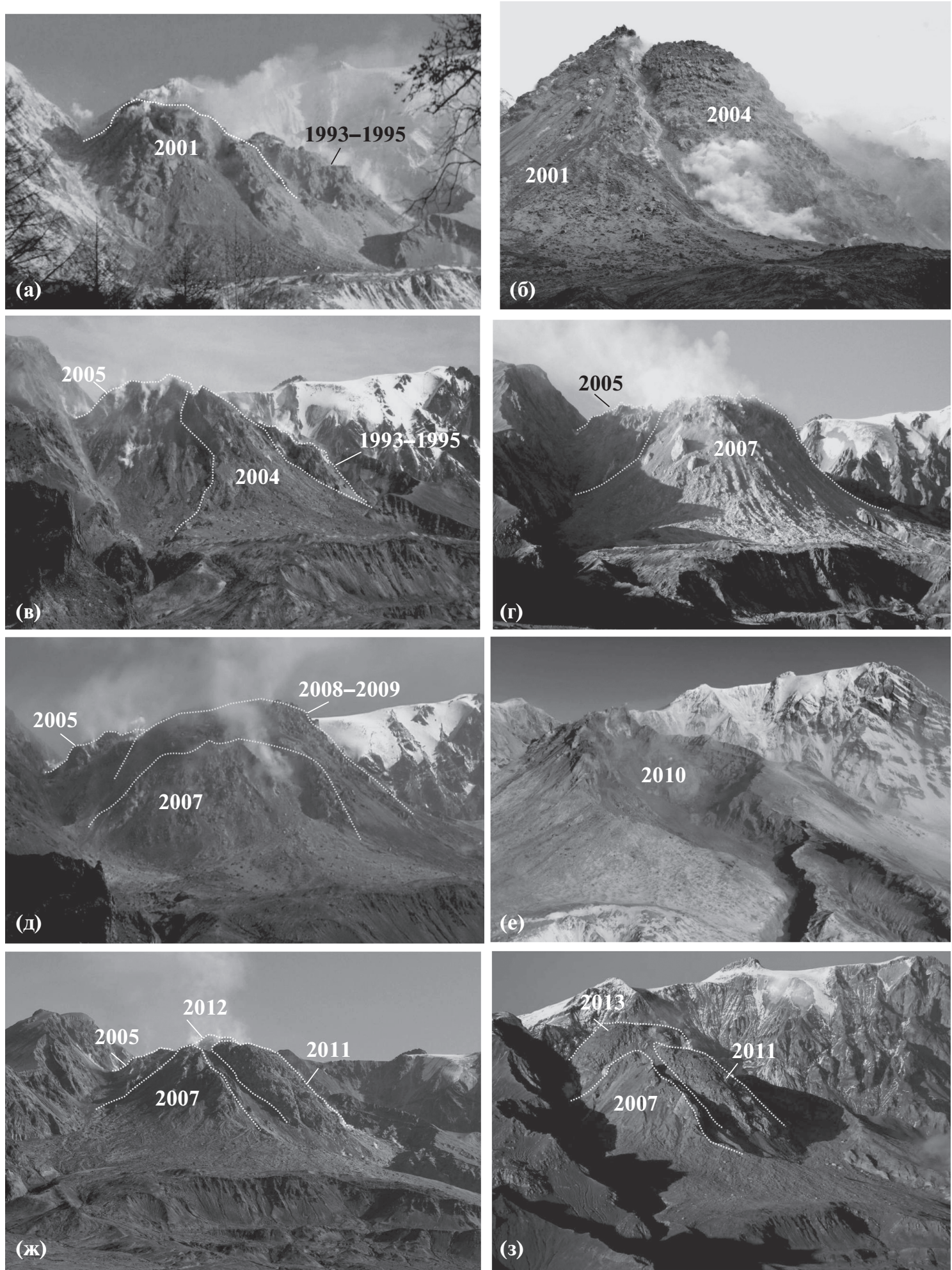

Рис. 2. Изменение морфологии растущего экструзивного купола в 2001-2013 гг. Фото А.В. Сокоренко (а), М.Е. Зеленского (б), Н.В. Горбач (в, г), Ю.В. Демянчука (д-3).

В октябре 1994 г. на вулкане наступил период относительного покоя со слабой или умеренной фумарольной деятельностью. Единичные пепло- вые выбросы стали фиксироваться с 1997 г., а к 2000 г. число таких выбросов достигло 29 [Мелекесцев и др., 2004]. 


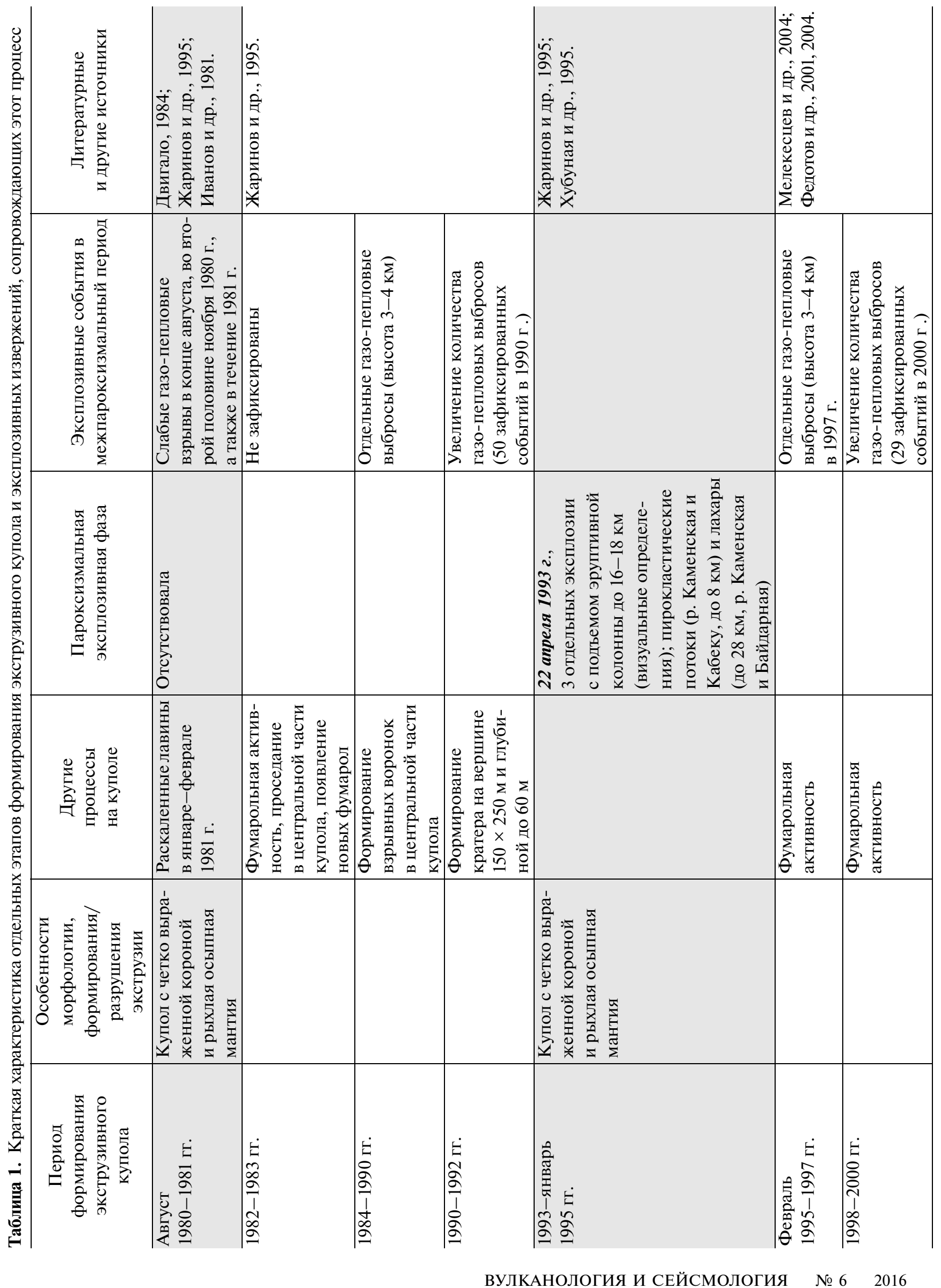




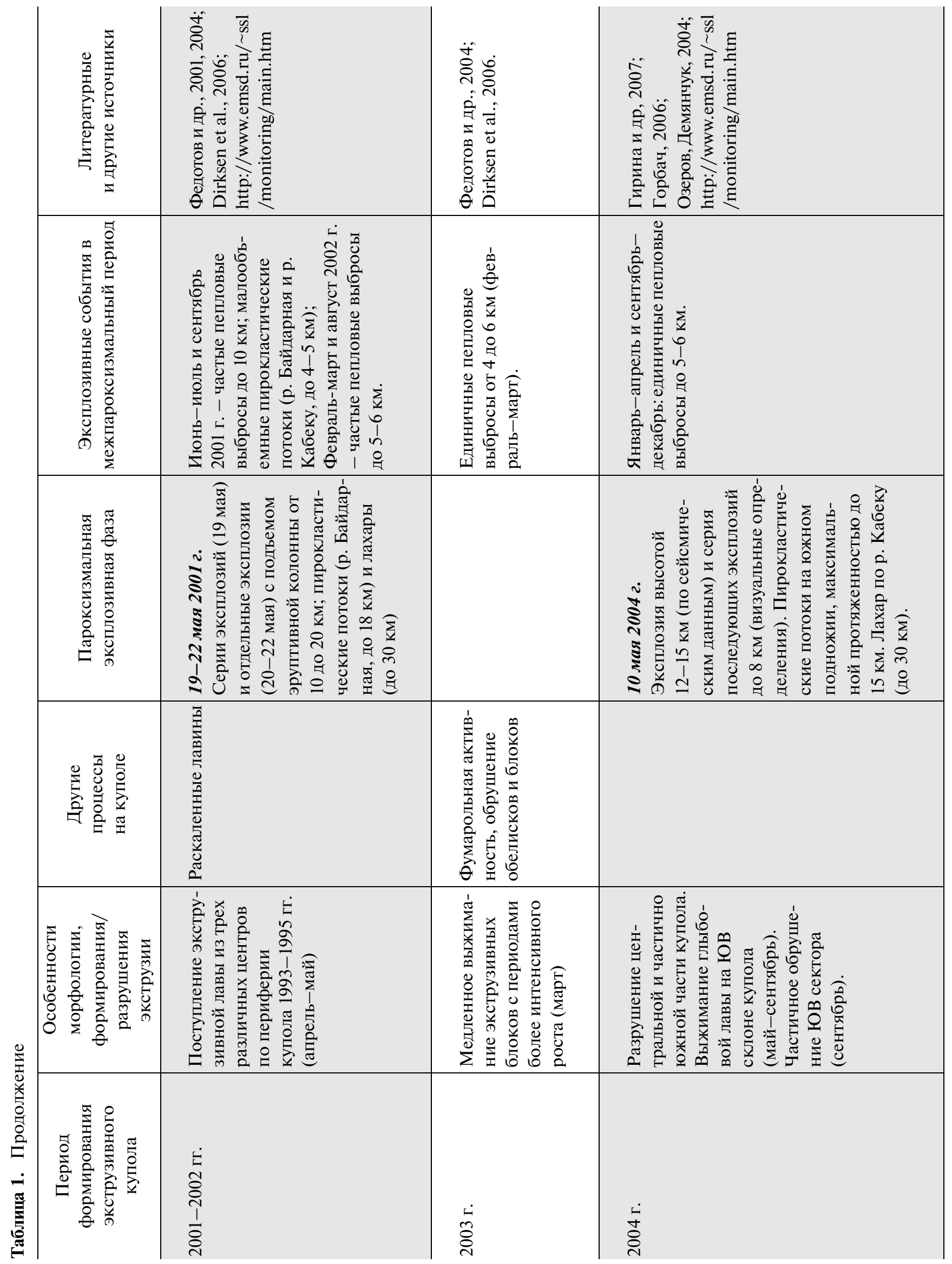




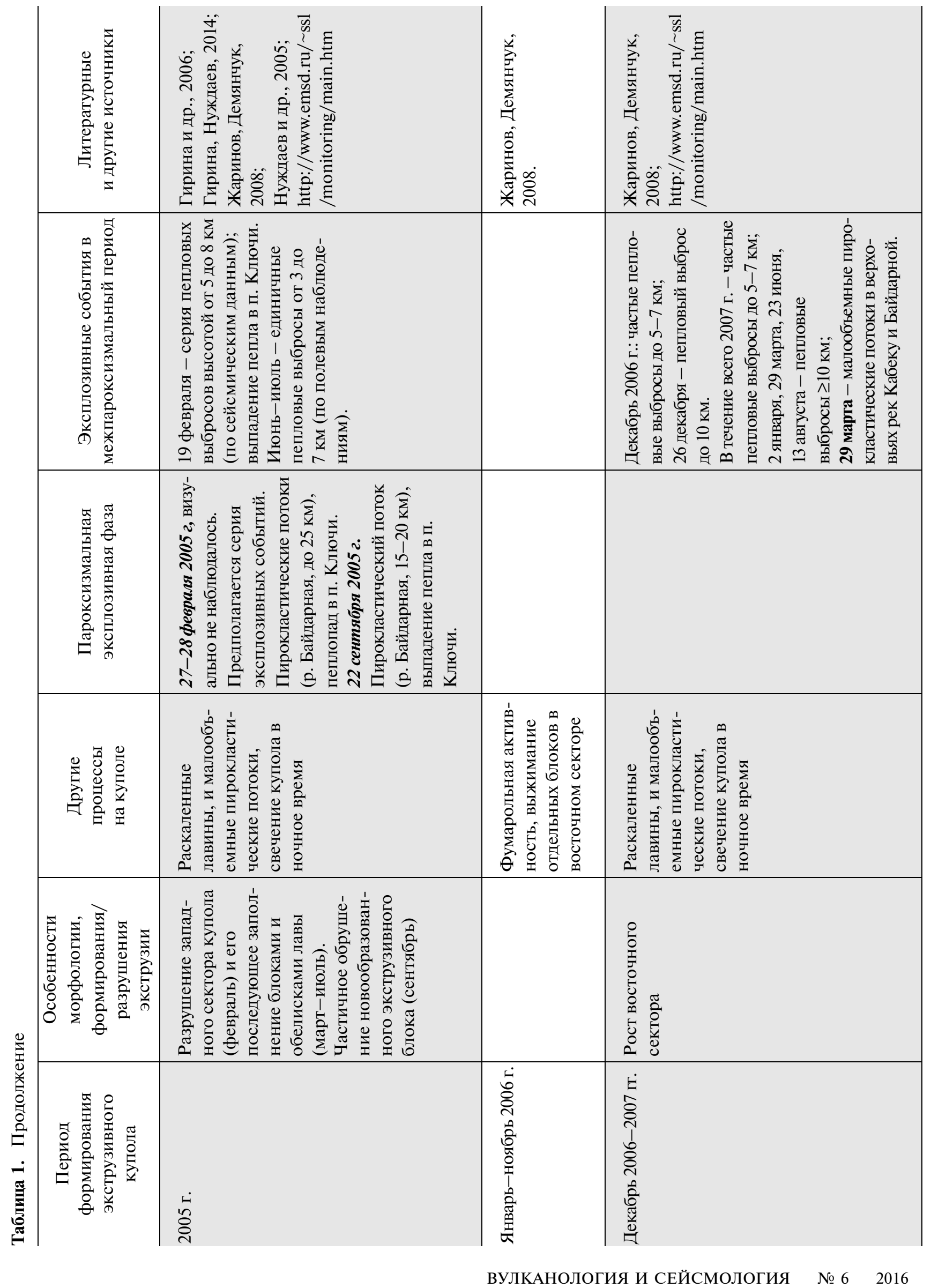




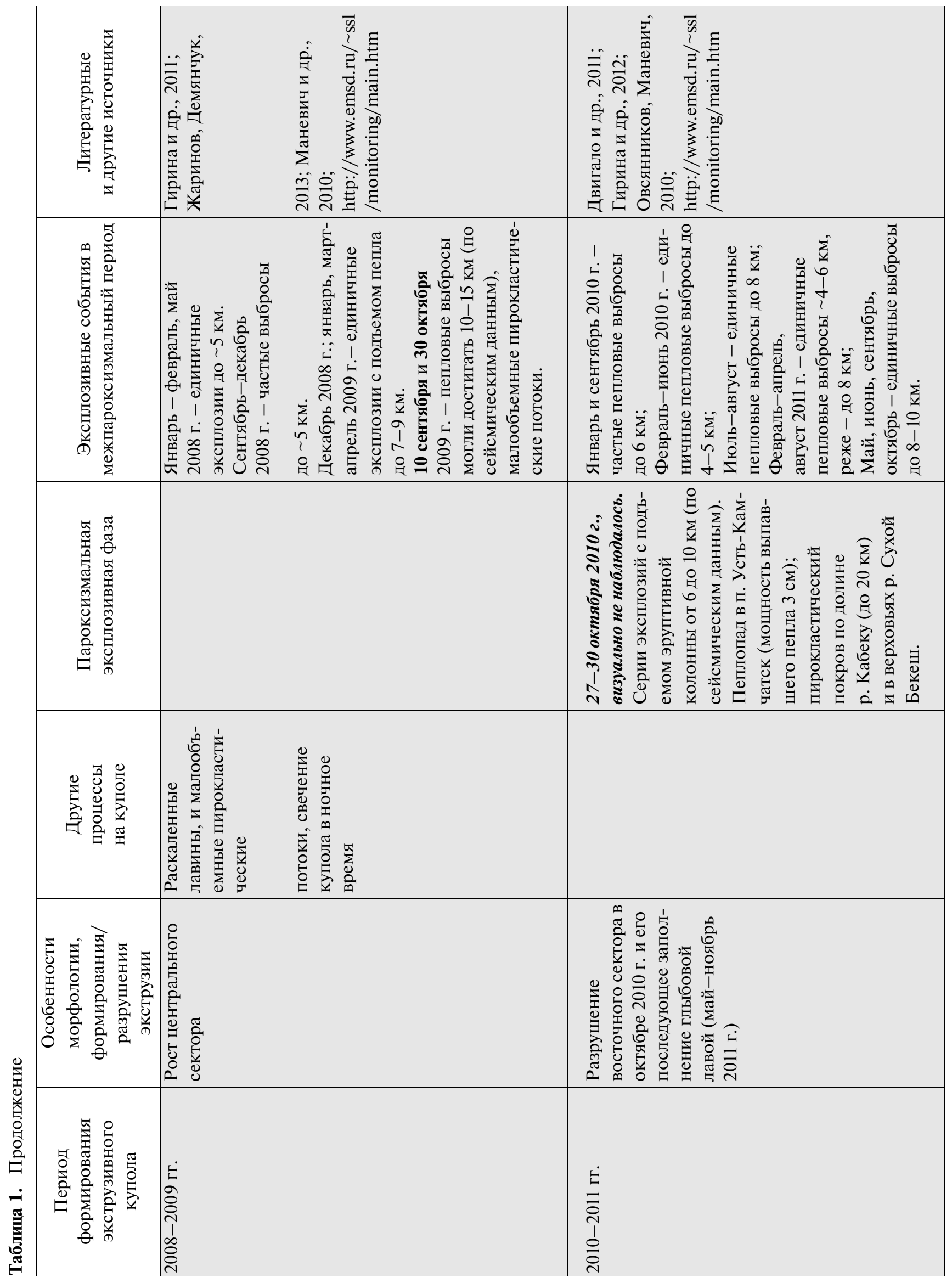




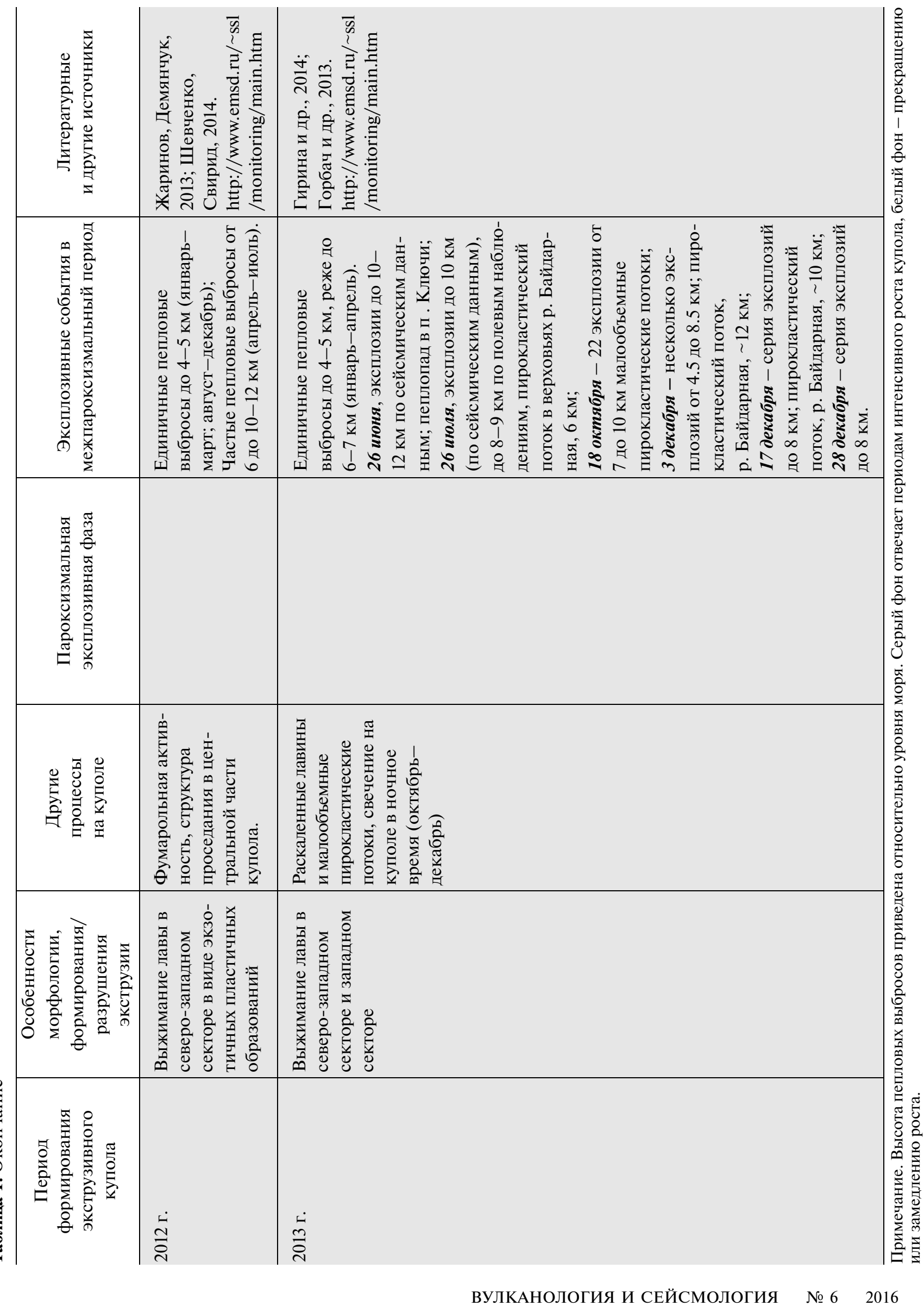


2001-2013 гг. - интенсивный рост купола, чередующийся с этапами его разрушения. С марта по начало мая 2001 г. на вулкане наблюдался рост числа сейсмических событий и интенсивности вулканического дрожания [Федотов и др., 2001]. В середине мая при помощи аэрофотосъемки были зафиксированы новые экструзивные образования, расположенные по периферии экструзивного купола 1993-1995 гг. [Федотов и др., 2001]. 19 мая последовала пароксизмальная эксплозивная фаза извержения: в течение нескольких часов серии пепловых выбросов сформировали эруптивную колонну, ширина которой была соизмерима с основанием постройки вулкана. Пирокластические и грязевые потоки распространялись по долинам рек Байдарной, Каменской и Кабеку. Одиночные мощные эксплозии с подъемом эруптивной колонны от 13 до 20 км н.У.м. продолжались и 20-22 мая [Федотов и др., 2001; 2004]. Максимальная скорость роста экструзии (до $11 \mathrm{~m}^{3} / \mathrm{c}$ ) наблюдалась в течение 16 дней предшествовавших главной эксплозивной фазе [Dirksen et al., 2006], и оставалась высокой в течение нескольких недель после пароксизмального извержения. В 2003 г. рост купола приостановился, только в отдельные периоды выжимались обелиски и блоки [Dirksen et al., 2006]. К этому времени объем экструзии составил $\sim 0.3$ км$^{3}$ [Федотов и др., 2004; Жаринов, Демянчук, 2008]. В работе [Shevchenko et al., 2015] приведена несколько большая оценка $-0.47 \mathrm{KM}^{3}$.

В мае 2004 г. произошло новое пароксизмальное извержение с разрушением центрального сектора купола и формированием пирокластических потоков на южном подножии [Гирина и др., 2006; Озеров, Демянчук, 2004]. После извержения внедрение жестких экструзивных блоков в вершинной части купола сменилось выжиманием глыбовой лавы (см. рис. 2б) на его юго-восточный склон [Горбач, 2006].

27-28 февраля 2005 г. произошло эксплозивное извержение, в ходе которого был разрушен западный сектор купола, уничтожена сейсмическая станция в 8-ми км от его подножия, а пирокластические потоки распространились на расстояние более 25 км от центра извержения [Гирина и др., 2006; Жаринов, Демянчук, 2013; и др.] Объем разрушений экструзивного купола оценивается от $0.04 \mathrm{~km}^{3}$ [Жаринов, Демянчук, 2013] до $0.11 \mathrm{KM}^{3}$ [Shevchenko et al., 2015].

С марта по сентябрь 2005 г. разрушенный сектор купола был полностью заполнен новообразованными экструзивными блоками (см. рис. 2в). В июле, по данным маршрутных обследований, экструзия имела ярко выраженное секторное строение. Восточный, неактивный сектор, имел массивный облик, в его верхней части хорошо выделялись два крупных блока-пластины с зубча- тыми вершинами. Активно растущий западный сектор имел крутую (до $70^{\circ}$ ) южную стенку, а его верхняя часть была сложена нагромождением подвижных глыб и блоков. В августе в верхней части растущего блока стали отмечаться нависающие блоки пластичной лавы [Гирина, Нуждаев, 2014], а 22 сентября произошло извержение, частично разрушившее новообразованный блок.

С января по начало декабря 2006 г. рост экструзии приостановился. Этот период характеризуется, преимущественно, фумарольной деятельностью. После возобновления эксплозивной и экструзивной активности в декабре 2006 г. начался интенсивный рост восточного и центрального секторов купола - только за первые шесть месяцев 2007 г. поступило $0.072 \mathrm{KM}^{3}$ лавы [Жаринов, Демянчук, 2008]. Экструзия вновь приобрела куполообразную морфологию с хорошо выраженной короной, сложенной растущими блоками и обелисками лавы (см. рис. 2г). В 2008-2009 гг. лава продолжала поступать в центральном и восточном секторе (см. рис. 2д).

В октябре 2010 г. значительная часть экструзивного купола снова была разрушена (см. рис. 2е) и сформирован обширный пирокластический покров в долинах рек Кабеку и Сухой Бекеш [Жаринов, Демянчук, 2013; Овсянников, Маневич, 2010]. В работе [Двигало и др., 2011] объем разрушений купола оценивается в $0.28 \mathrm{~km}^{3}$.

В 2011 г. разрушенный ЮВ сектор купола был заполнен глыбовой лавой (см. рис. 2ж), в виде глыбового панциря или лавового потока [Жаринов, Демянчук, 2013; Шевченко и др., 2014]. В середине 2012 г. лава поступала в С3 секторе купола (см. рис. 23) в форме экзотичных образований, названных в работе [Шевченко и др., 2014] “структурами расщепления". С апреля по июль 2012 г. на растущем куполе произошло около 20 эксплозивных событий с подъемом пепла от 7 до 12 км н.у.м (http://www.emsd.ru/ ssl/monitoring). На протяжении 2013 г. лава продолжала выжиматься в западном и северо-западном секторе (см. рис. 23) [Гирина и др., 2014а]. Во второй половине 2013 г. произошло несколько мощных эксплозивных событий с формированием малообъемных пирокластических потоков (см. табл. 1).

Общие черты отложений пирокластических потоков извержений 2001-2013 гг. Отложения пирокластических потоков, изверженных с 2001 по

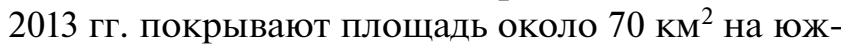
ном подножии вулкана и обрамляют отложения обломочной лавины извержения 1964 г. (рис. 3a). Пирокластические потоки распространялись в юго-западном (долина реки Байдарной), юго-восточном (долина реки Кабеку), реже - в южном направлении от растущего экструзивного купола (верховья реки Каменской). Формирование пирокластических потоков было связано, преимуще- 


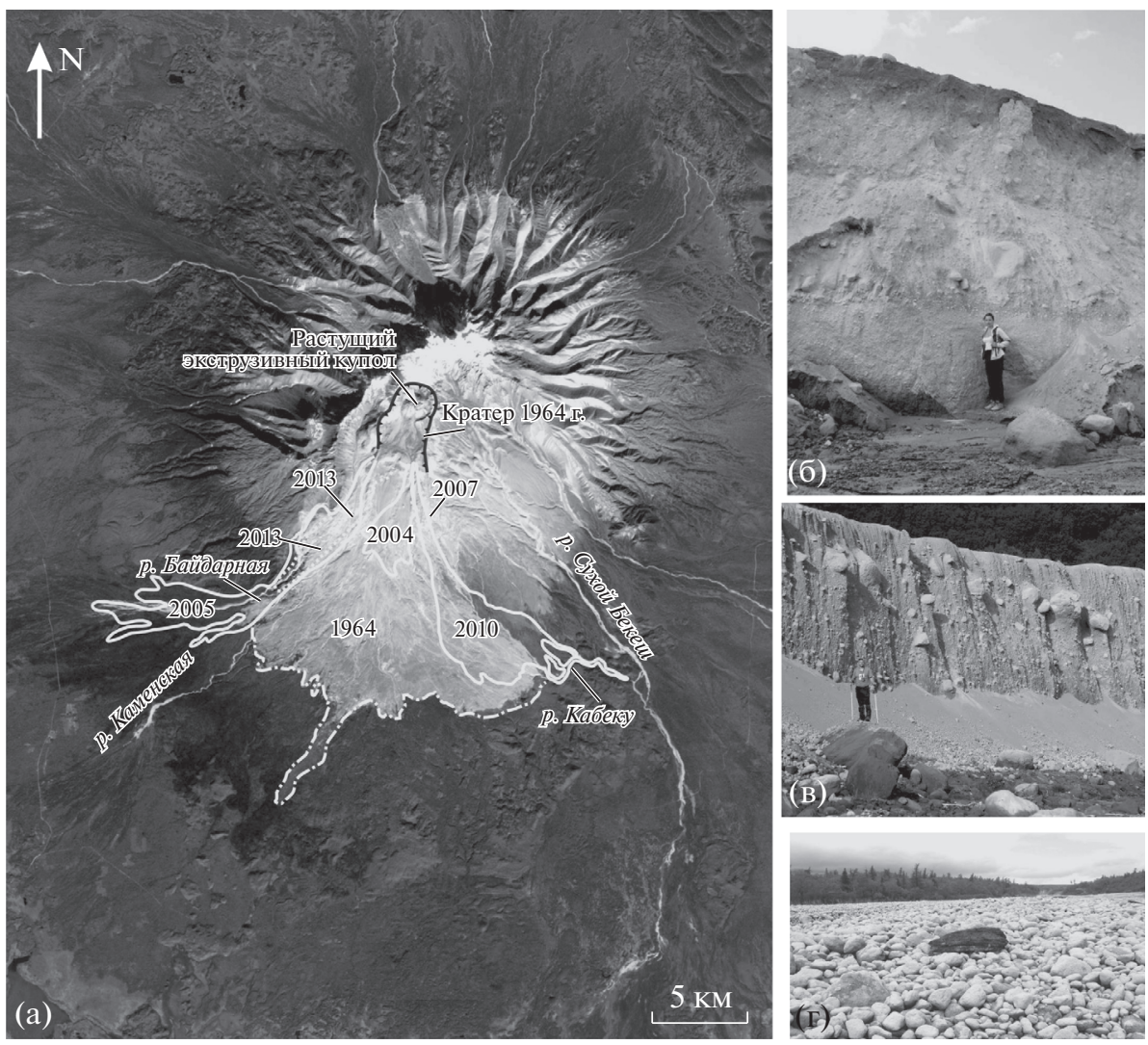

Рис. 3. Распространение и характер отложений крупнейших пирокластических потоков в 2001-2013 гг.: а - схема распространения пирокластических потоков; б - пирокластические отложения извержения 27-28 февраля 2005 г. в 15 км от центра извержения; в - пирокластические отложения извержения 28 октрября 2010 г в 13 км от центра извержения; г - поверхность пемзовидных отложений пирокластического потока 19 мая 2001 г.

ственно, с разрушением отдельных блоков купола в ходе эксплозивных событий. Облик отложений таких пирокластических потоков определяется присутствием разноразмерных глыб (от первых десятков см до нескольких метров), погруженных в гравийно-пылевато-песчаный матрикс (см. рис. 3б и 3в). Количество крупнообломочного материала в таких отложениях составляет от 20 до 40\%. Типичными пеплово-глыбовыми пирокластическими потоками представлены отложения, изверженные в мае 2004 г., в 2007 г., и в сентябре 2005 г. Для ряда событий описаны и отложения пирокластических волн [Гирина и др., 2007; Нуждаев и др., 2005]. Облик отложений, изверженных в октябре 2010 г. (см. рис. 3в), также имеет черты пеплово-глыбового пирокластического потока [Овсянников, Маневич, 2010].

Ювенильный пемзовидный материал в наибольшем количестве был отмечен в отложениях пирокластического потока 2001 г. (см. рис. 3г) [Федотов и др., 2001] и малообъемного потока, изверженного в июле 2013 г. [Горбач и др., 2013]. В отложениях крупнейших извержений в 2005 и 2010 гг. пемзовидные округлые обломки, размером от первых до 10-15 см присутствовали в ма- лом количестве и располагались в виде струй на поверхности отложений.

Оценка суммарного объема пирокластических отложений затруднительна в силу отсутствия прямых инструментальных данных. По полевым наблюдениям средняя мощность отложений изменяется от 1.5-2 м для малообъемных пирокластических потоков до 8-10 м для крупномасштабных событий. Однако в зонах максимальной аккумуляции материала, на расстояниях от 5 до 15 км к Ю3 и ЮВ от растущего экструзивного купола по долинам рек Байдарной и Кабеку, отложения пирокластических потоков многократно наслаивались, что значительно увеличивало их суммарную мощность. Так, пирокластические отложения, связанные с извержением в феврале 2005 г., в среднем течении реки Байдарной имели мощность до 20 м (наблюдения выполнены через 4 месяца после извержения). Эти отложения были перекрыты новым пирокластическим потоком мощностью в 4-5 м уже в сентябре 2005 г., а в последующие годы перекрывались подобными отложениями неоднократно (в 2007, 2008, 2009 и 2013 гг.). Если, с учетом зон максимальной аккумуляции пирокластического материала, среднюю 
мощность всех отложений, сформированных за последнее десятилетие, принять равной 8-9 м, то их суммарный объем приблизится к $\sim 0.6 \mathrm{KM}^{3}$. С учетом среднего содержания плотных обломков в отложениях $\sim 30 \%$ и плотности заполнителя пирокластических потоков по данным работ [Гирина и др., 2007, 2014], объем пирокластических отложений 2001-2013 гг. составит около 0.46 км$^{3}$ в пересчете на плотную породу. Количество ювенильного материала можно оценить, основываясь на данных о разрушениях экструзивного купола во время крупных эксплозивных извержений. Согласно работам [Двигало и др., 2011; Жаринов, Демянчук, 2008, 2013; Озеров, Демянчук, 2004; Shevchenko et al., 2015] суммарный объем разрушений равняется $\sim 0.4 \mathrm{kм}^{3}$. Таким образом, минимальное содержание ювенильного материала в отложениях пирокластических потоков 2001-2013 гг. составляет $0.06 \mathrm{KM}^{3}$.

Суммарный объем экструзивных лав и пирокластических продуктов, изверженных в 2001-2013 гг. B работе [Shevchenko et al., 2015] общий объем экструзивных лав, изверженных с 1980 г. по 2012 г., оценивается в $1.02 \mathrm{KM}^{3}$. Согласно данной оценке и с вычетом суммарного объема экструзивных лав ранних этапов роста в 1980-1981 гг. и 1993-1995 гг., с 2001 г. по 2012 г. на поверхность могло поступить не менее 0.82 км$^{3}$ андезитов. Минимальная оценка ювенильного материала в отложениях крупных пирокластических потоков, приведенная в предыдущем разделе, составляет $0.06 \mathrm{kм}^{3}$. Таким образом, даже без учета экструзивных лав, поступивших на поверхность в 2013 г., и без учета тефры, вынесенной за пределы постройки вулкана во время эксплозивных событий, объем материала, изверженного в 2000-х гг., может приближаться к $0.9 \mathrm{KM}^{3}$.

\section{ОТБОР ОБРАЗЦОВ И МЕТОДЫ ИССЛЕДОВАНИЯ}

Образцы лав со склонов растущего экструзивного купола или же из материала горячих лавин у его подножия удалось отобрать в 2003, 2004, 2005, 2007 и 2008 гг. Кроме того, отбирались образцы материала пирокластических потоков, изверженных с 2004 по 2013 гг. Образцы ювенильных пемзовидных андезитов, изверженных в мае 2001 г., были любезно предоставлены зав. музеем Института вулканологии и сейсмологии ДВО РАН С.А. Хубуная. Описание позиции, места отбора и привязка образцов к периоду извержения приведены в таблице 2. Для определения химического и минералогического составов использовались образцы, имеющие точную временную привязку к периоду извержения.

Количественно-минералогический состав и пористость андезитов определялись при помощи оптического микроскопа, а для представитель- ных образцов были выполнены определения с использованием электронного сканирующего микроскопа SEM Vega Tescan в Институте экспериментальной минералогии РАН в г. Черноголовка.

Химический состав представительных образцов андезитов определялся рентгенофлюоресцентным методом на спектрометре Phillips X 'Unique PW1480 в Центре исследований океана им. Гельмгольца (Helmholtz Centre for Ocean Research Kiel, GEOMAR, г. Киль, ФРГ) и в лаборатории AcmeLab (г. Ванкувер, Канада). Вместе с образцами анализировались международные стандарты пород JB-2, JB-3 и JА-2. Для продуктов, изверженных в 2001-2002 гг., дополнительно были использованы данные из работ [Dirksen et al., 2006; Humphryes et al., 2006].

Состав породообразующих минералов и интерстициальных стекол был изучен в аншлифах при помощи электронного зонда с энергодисперсионным спектрометром Oxford Instruments X-max 80 в Институте вулканологии и сейсмологии ДВО РАН. Условия анализа составляли: напряжение 20 кВ и ток 40 нА. В качестве стандартов использовались природные силикаты: санидин для $\mathrm{Si}, \mathrm{Na}, \mathrm{Al}, \mathrm{K}$; диопсид для Са и $\mathrm{Mg}$; оливин для $\mathrm{Fe}$; ильменит для Ті и родонит для $\mathrm{Mn}$. Часть породообразующих минералов была проанализирована также на электронном зонде JEOL JXA-8200 в Helmholtz Centre for Ocean Research Kiel (GEOMAR, г. Киль, ФРГ), оборудованном пятью спектрометрами с дисперсией по длинам волн. Анализ проводился при ускоряющем напряжении 15 кВ и токе зонда 20 нА для плагиоклаза, амфибола и пироксена. Для контроля качества анализов использовались международные стандарты для электронно-зондового микроанализа [Jarosevich et al., 1980]. Дополнительные анализы интерстициальных стекол были также заимствованы из работ [Пономарева и др., 2012; Ponomareva et al., 2015].

\section{ВЕЩЕСТВЕННЫЙ СОСТАВ АНДЕЗИТОВ 2001-2013 ГГ.}

Петрография пород и их текстурные особенности. Роговообманково-плагиоклазовые андезиты современного экструзивного купола и их обломки в отложениях пирокластических потоков порфировые и серийно-порфировые породы преобладающих серых, буровато-серых или бурых оттенков. Для пемзовидных разностей андезитов характерны более светлые бежевые и белые тона. Андезиты имеют разнообразные и неоднородные текстуры. Среди экструзивных лав наиболее распространенными являются полосчатые текстуры, которые образованы за счет ориентированных скоплений фенокристаллов роговой обманки (рис. 4a). Еще один часто встречающийся тип полосчатости обусловлен чередованием серых и бурых, в различной степени окисленных участков. 


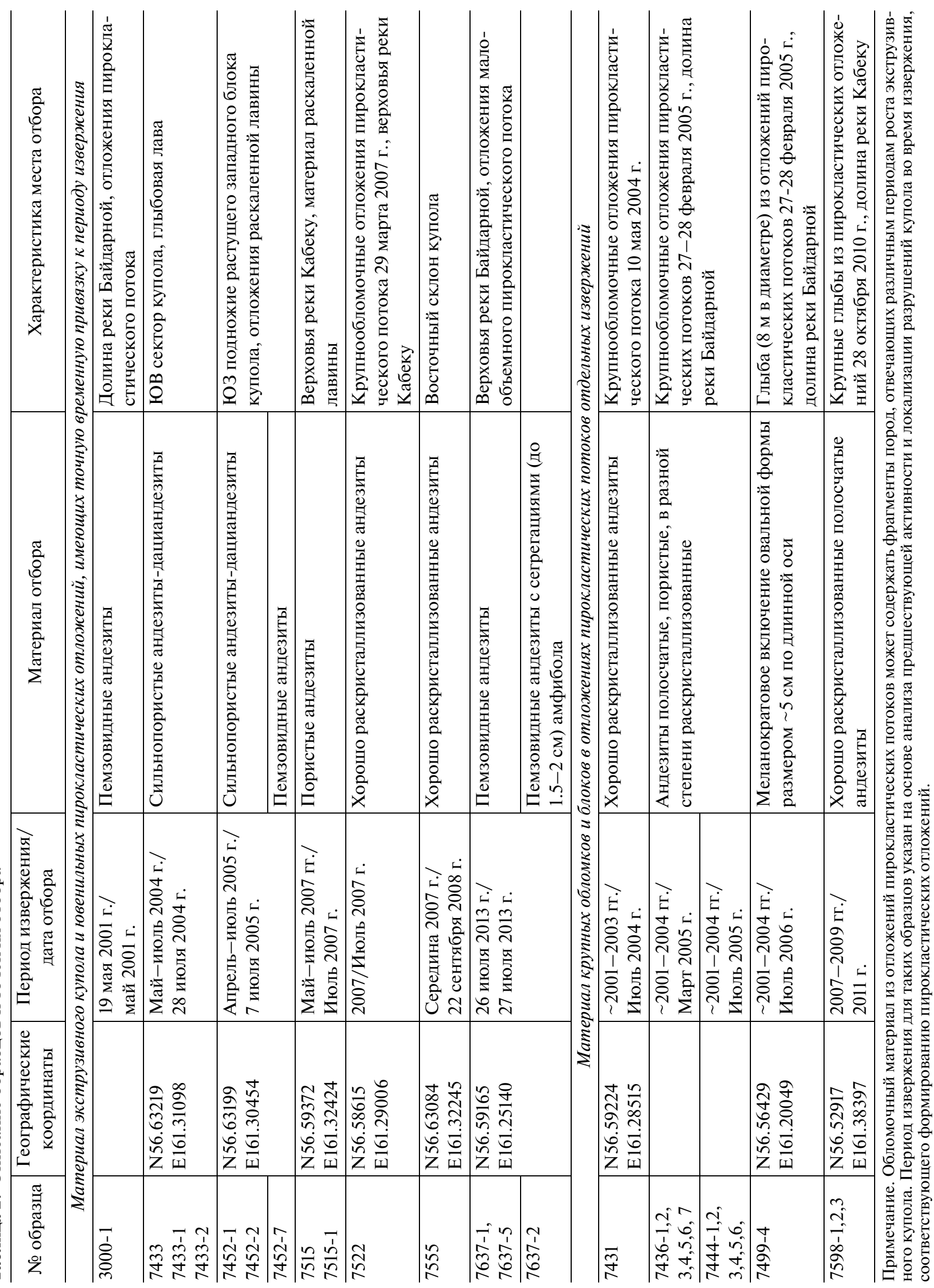



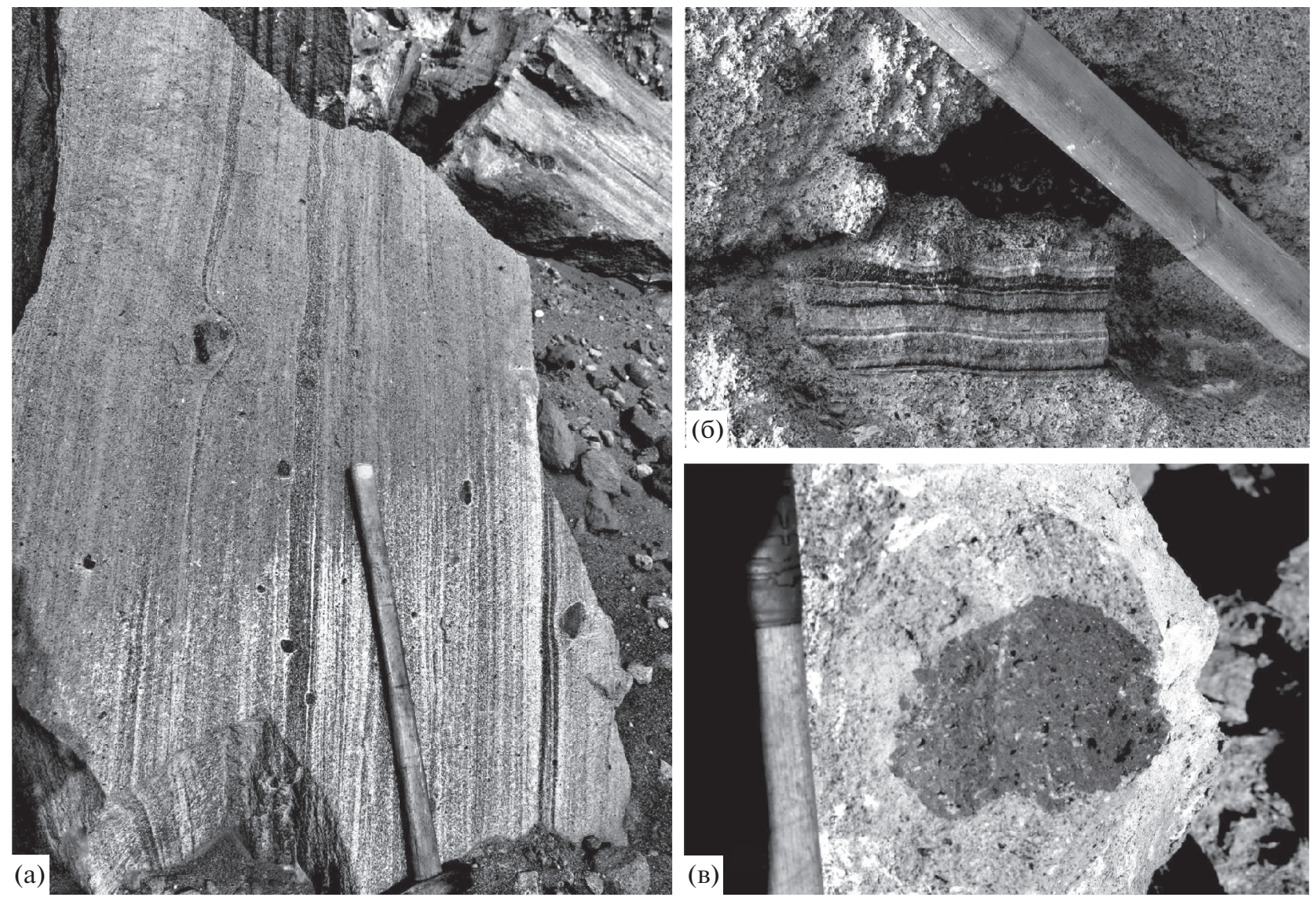

Рис. 4. Экструзивные лавы.

a - блок лавы с полосчатой текстурой; б - ритмично-расслоенное включение в блоке андезитов из пирокластических отложений, 22 сентября 2005 г.; в - включение андезибазальтового состава в глыбе пирокластического потока, 27-28 февраля 2005 г.

Неоднородные текстуры лав и пемзовидных пирокластических продуктов формируются также за счет часто встречающихся сегрегаций роговой обманки в виде пятен и шлиров, а также большого количества гомеогенных включений и ксенолитов. Гомеогенные включения имеют диоритовый или габбро-диоритовый облик, а среди ксенолитов наиболее распространены типичные для Молодого Шивелуча амфиболиты и амфиболитизированые пироксениты. В крупных блоках отложений пирокластических потоков, изверженных в 2005 г., были найдены и нетипичные включения. На рис. 4б показано одно из таких включений, которое было впаяно в газовую полость-каверну. Это ритмично-расслоенная порода, имеющая переход к “нормальной” лаве. Возможно, это включение является примером процесса кристаллизации, который происходит у стенок магматического канала или камеры. В этих же отложениях было описано богатое оливином и амфиболом включение (см. рис. 4в), которое по особенностям текстуры и состава минералов [Горбач, Портнягин,
2011; Gorbach, 2006] интерпретируется как закаленный фрагмент мафической магмы.

Все изученные образцы андезитов пористые количество пор в образцах экструзивных лав составляет 15-20 об. \%, а в пемзовидных разностях достигает 45-50 об. \%. Общее количество вкрапленников варьирует от $\sim 35-50$ об. \% в экструзивных лавах до $\sim 15$ об. \% в их наименее раскристаллизованных разностях и пемзовидных продуктах. На рис. 5 показаны примеры представительных образцов, для которых количественно-минералогические характеристики и пористость оценивались при помощи сканирующего электронного микроскопа.

Плагиоклаз (10-25 об. \%) и роговая обманка (7-15 об. \%) преобладают во вкрапленниках и представлены несколькими генерациями кристаллов по размерности и химическому составу. Орто- и клинопироксены (не более 2 об. \%) образуют субфенокристаллы и микролиты. Практически в каждом изученном образце присутствуют единичные кристаллы оливина $\left(\mathrm{Fo}_{80-88}\right)$, заключенные в реакционную кайму из ортопироксена, 

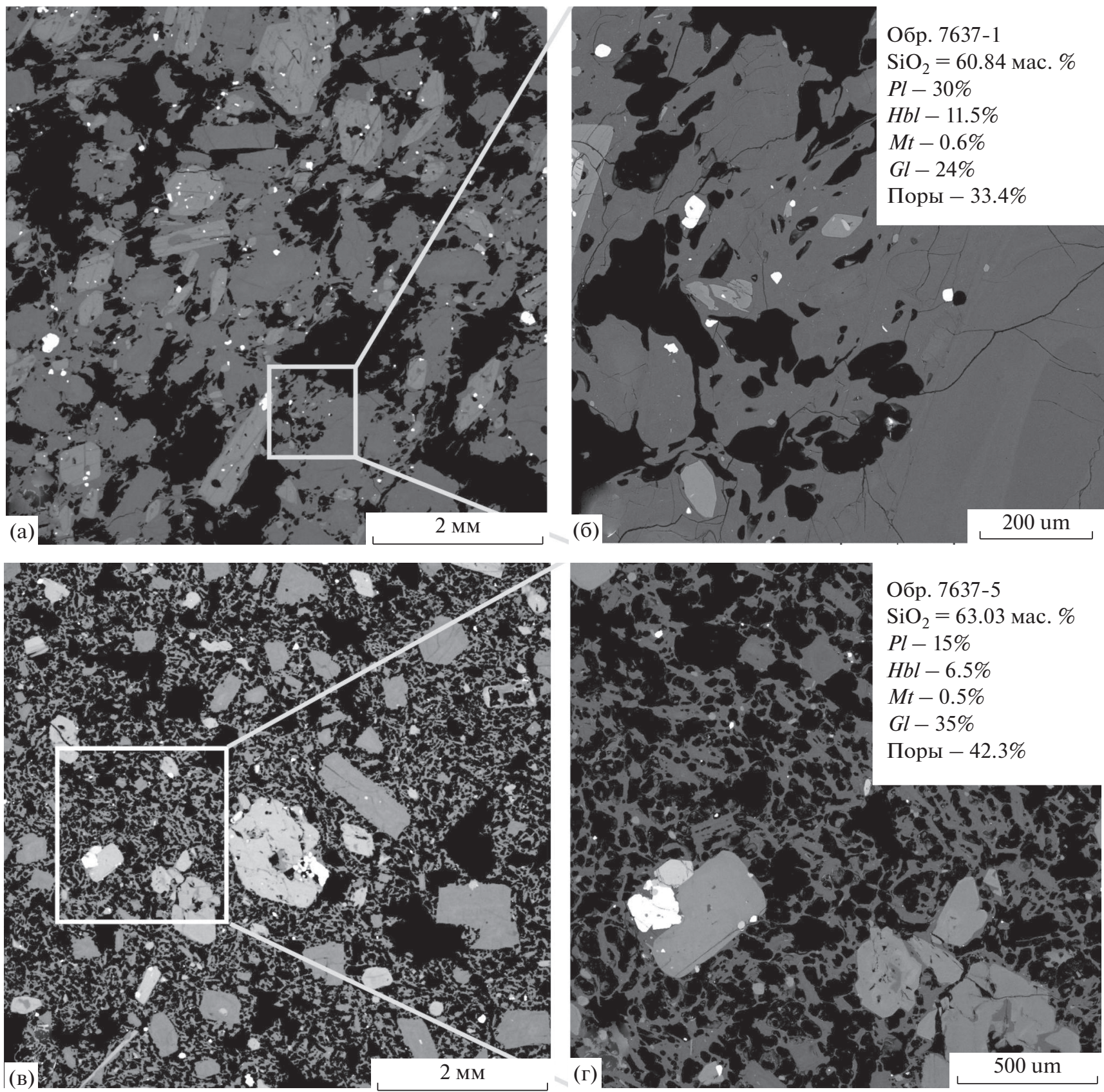

Рис. 5. Микроскопический облик пемзовидных андезитов, изверженных в июле 2013 г. и их количественно-минералогические характеристики. Изображения в режиме отраженных электронов выполнены при различном увеличении на сканирующем электронном микроскопе SEM VEGA Teskan.

$\mathrm{Fe}-\mathrm{Ti}$ оксидов и амфибола, приуроченного к внешней зоне каймы. Рудный минерал (титаномагнетит и магнетит) присутствует в небольшом количестве (около 1 об. \%) в основной массе пород и в качестве включений в темноцветных минералах. В качестве акцессорной фазы в породах отмечается также апатит, который образует редкие мелкие субфенокристаллы и включения во вкрапленниках плагиоклаза и амфибола. Основная масса андезитов состоит из микролитов пла- гиоклаза, небольшого количества пироксенов, рудного минерала и риолитового стекла. В отдельных разностях пород среди микролитов присутствует и роговая обманка.

Состав породообразующих минералов и интерстициальных стекол. Вкрапленники плагиоклаза андезитов современного экструзивного купола имеют широкие вариации состава и обладают сложной зональностью и разнообразием текстур. Центральные и внутренние зоны вкрапленников 


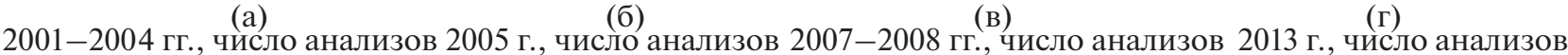

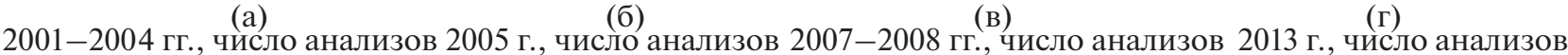

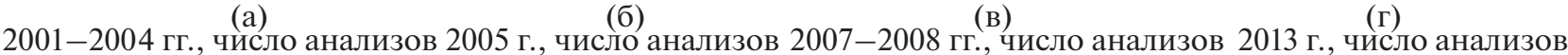

(г)
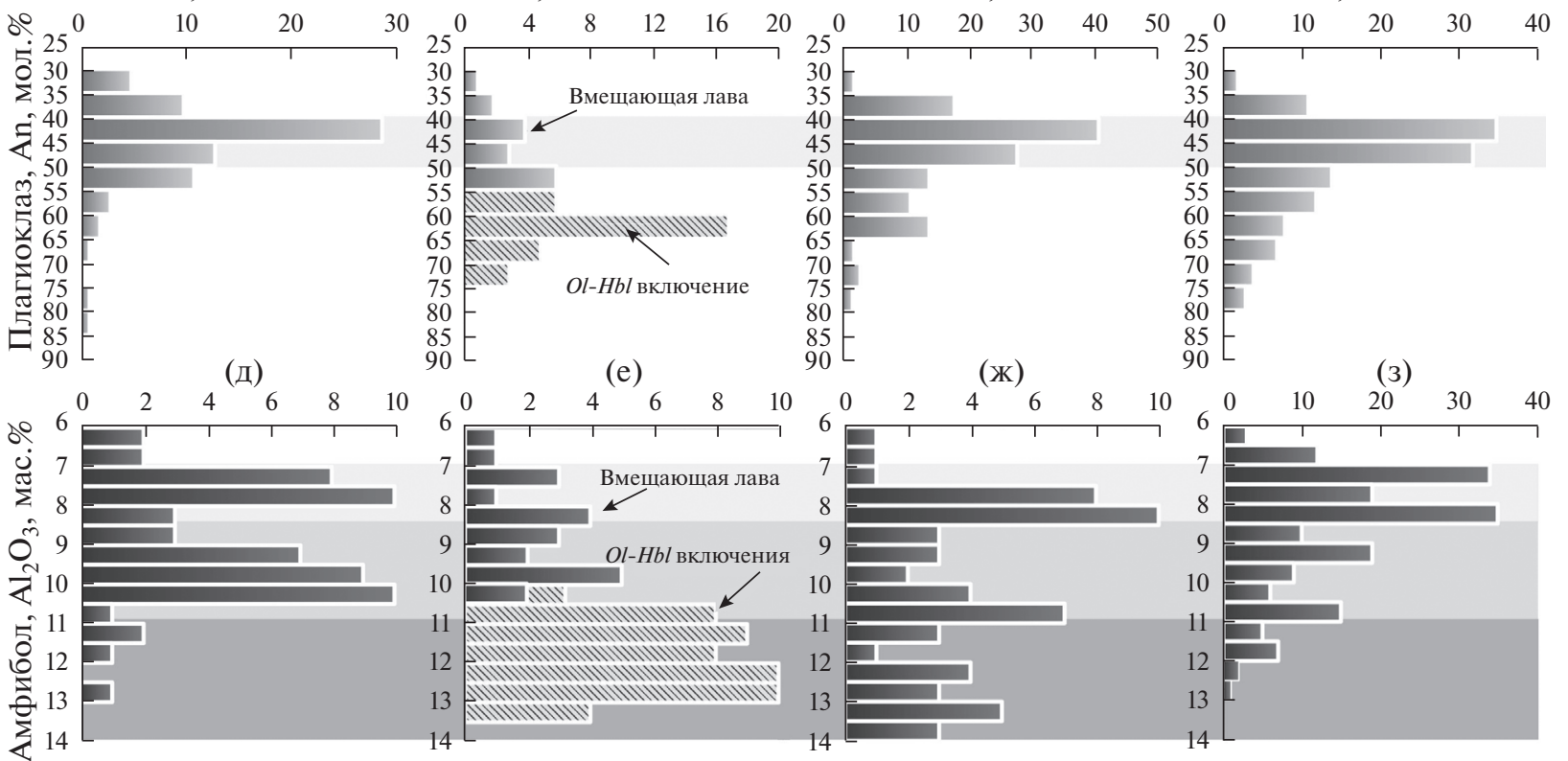

Рис. 6. Состав вкрапленников роговой обманки и плагиоклаза в андезитах экструзивного купола, изверженных в 2001-2013 гг. Использованы составы центральных и внутренних зон кристаллов.

варьируют по составу от $A n_{30}$ до $A n_{83-88}$, а краевые зоны кристаллов и микролитов - от $A n_{48}$ до $A n_{25}$. На рис. 6а, 6б, 6в, 6г показаны гистограммы составов вкрапленников плагиоклаза для андезитов, изверженных в различные периоды формирования купола. Во всех образцах преобладают андезины $A n_{40-50}$. Количество высококальциевых плагиоклазов с содержанием анортита более 70 мол. \% значительно меньше, однако, такие вкрапленники отмечаются во всех образцах. Плагиоклазы из Ol-Hbl меланократового включения выделяются на фоне всех образцов резко преобладающим составом $A n_{60-65}$.

Основные типы зональности плагиоклазов были выделены и детально описаны ранее в продуктах извержения 2001 г. [Humphreys et al., 2006], а также в лавах, изверженных в 2004-2005 гг. и 2007 г. [Горбач, 2006; Горбач, Портнягин, 2011]. Сходные типы присутствуют и в породах последующих извержений. На рис. 7а, 7б, 7в показаны примеры наиболее распространенных типов зональности плагиоклазов в андезитах, изверженных в июле 2013 г. Преобладающими типами являются ритмично-зональные андезины с тенденцией понижения анортита к краю зерна и обратно зональные плагиоклазы, имеющие вокруг ядра широкую кальциевую зону (см. рис. 7а и 7б). Плагиоклазы с реликтом высококальциевого ядра (см. рис. 7в) являются менее распространенными, однако, как уже было отмечено, присутствуют в каждом изученном образце.
Амфиболь в большинстве образцов присутствуют в виде двух генераций фенокристаллов, которые отличаются размером и текстурой. Первую генерацию представляют крупные ( $\geq 1.5-2$ мм) кристаллы с неоднородным пятнистым ядром, переполненные включениями плагиоклаза, ортопироксена, расплава и рудного минерала. Вторая генерация вкрапленников имеет размер $\geq 1-1.2$ мм, часто содержит включения плагиоклаза, а иногда образует сростки с ним. В отдельных разностях пород помимо перечисленных генераций присутствуют также субфенокристаллы (0.3-0.5 мм) и микролиты (0.1-0.2 мм). Большинство кристаллов идиоморфны, опацитизированные амфиболы встречаются редко, а зерна в реакционной $\mathrm{Pl}-\mathrm{Px}-\mathrm{Mt}$ кайме единичны. В пемзовидных продуктах, изверженных в июле 2013 г., присутствуют амфиболы с признаками быстрого роста в виде многочисленных заливов стекла.

Химический состав амфиболов отвечает преобладающей магнезиальной роговой обманке, магнезиогастингситу и паргаситу по [Leake et al., 1997]. Большинство вкрапленников обладает зональностью, которая отчетливо проявлена в вариациях содержаний алюминия, натрия, титана и Mg\#. На рис. 6д, 6е, 6ж, $6 з$ показано распределение содержаний $\mathrm{Al}_{2} \mathrm{O}_{3}$, как одного из компонентов, наиболее чувствительных к изменениям условий кристаллизации, в ядрах и внутренних зонах вкрапленников амфибола в породах, отвечающих различным этапам роста купола. Распределение содержаний крайне неравномерно - во 

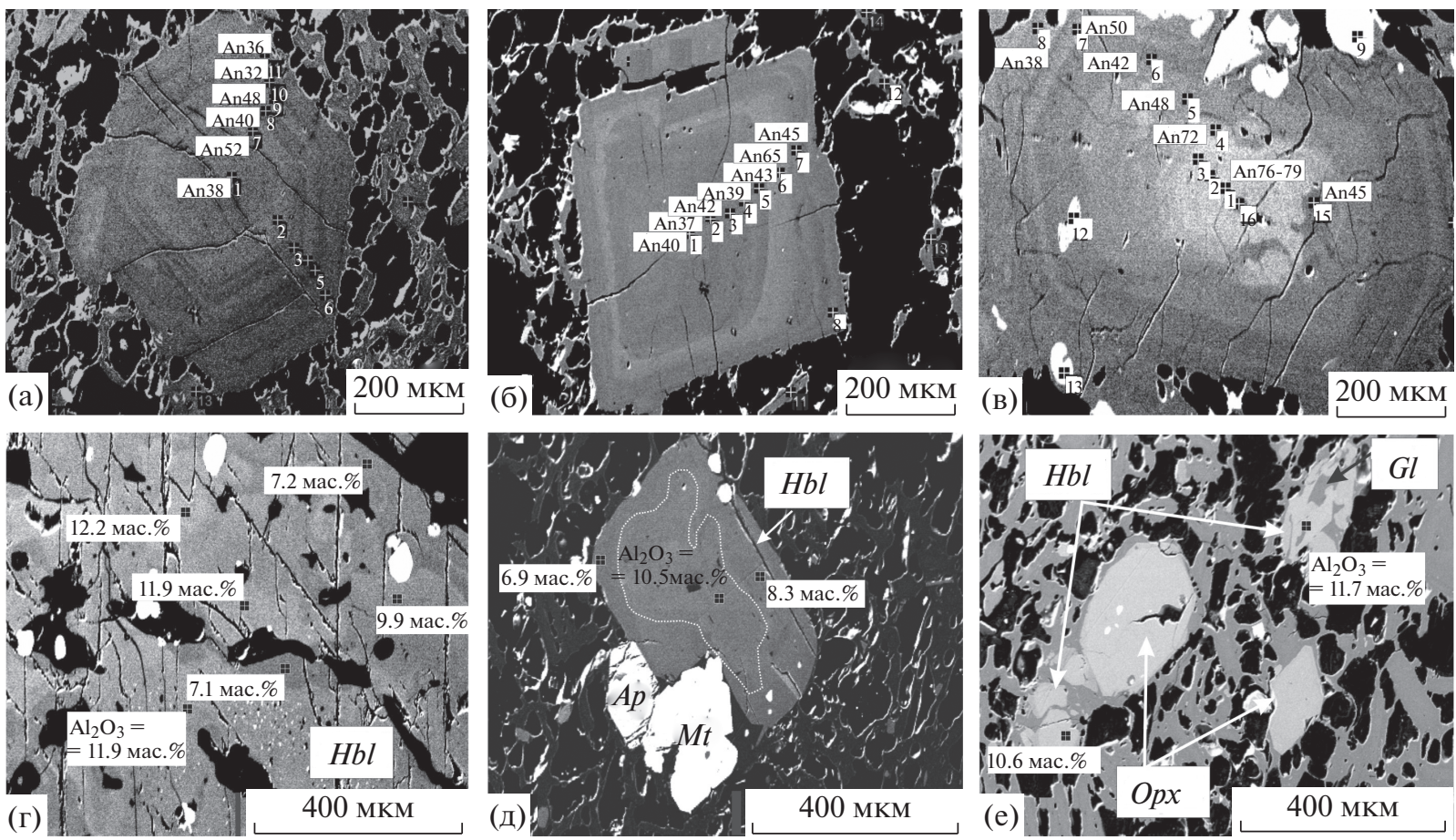

Рис. 7. Примеры зональности вкрапленников плагиоклаза и роговой обманки в андезитах экструзивного купола. $\mathrm{a}$ - плагиоклаз $\mathrm{An}_{52-32}$ с тонкой ритмичной зональностью; б - ядро плагиоклаза среднего состава $\mathrm{An}_{40}$ окружено широкой кальциевой зоной $\mathrm{An}_{65}$; в - ядро высококальциевого плагиоклаза $\left(\mathrm{An}_{76-79}\right)$ окружено кислой ритмично-зональной каймой; г - фрагмент крупного кристалла роговой обманки с пятнистой зональностью, зоной резорбции и обильными включениями стекла и рудного минерала; д - вкрапленник роговой обманки с нормальной зональностью; е - субфенокристаллы роговой обманки с высоким содержанием глинозема. $\mathrm{Hbl}$ - роговая обманка; $\mathrm{Pl}$ - плагиоклаз; Орх - ортопироксен; Ap - апатит; Mt - магнетит; Gl - стекло.

всех образцах содержания глинозема варьируют от 6 до 13-14 мас. \% и имеют несколько пиков распределения. Первый пик совпадает для всех образцов и отвечает по составу преобладающей магнезиальной роговой обманке. Второй пик наиболее отчетливо выражен в продуктах извержений 2001 и 2004 гг., но прослеживается и в других образцах. Этому пику часто отвечают ядра или внутренние зоны зональных кристаллов. ВысокоAl амфиболы в продуктах извержений 2001-2004 гг. отмечаются в небольшом количестве, в продуктах же последующих извержений формируют еще один хорошо выраженный пик, а также резко преобладают среди амфиболов меланократового Ol- $\mathrm{Hbl}$ включения.

Значительные вариации содержаний алюминия обнаруживаются и в пределах отдельных зерен. Рис. 7г иллюстрирует пятнистую зональность крупного кристалла амфибола с зоной резорбции и многочисленными включениями стекла и магнетита. На рис. 7д показан пример вкрапленника, в котором снижение содержаний $\mathrm{Al}_{2} \mathrm{O}_{3}$ наблюдается к краям, что соответствует прямой зональности и отражает понижение температуры и давления при кристаллизации. В некоторых случаях встречается и “обратная" зональность - к краям зерен фикси- руется рост содержаний $\mathrm{Al}_{2} \mathrm{O}_{3}$ (а также $\mathrm{Na}_{2} \mathrm{O}$ и $\mathrm{TiO}_{2}$ ) при снижении магнезиальности. К примеру, вкрапленники с высокоглиноземистой каймой типичны для зоны контакта меланократового андезибазальтового включения с вмещающим андезитом. Высокоглиноземистым составом отличаются также отдельные субфенокристаллы и микролиты продуктов, изверженых в июле 2013 г. (см. рис. 7е).

Немногочисленные субфенокристаллы и микролиты орто- и клинопироксенов обладают достаточно выдержанным составом во всех образцах андезитов, изверженных в 2001-2013 гг. Клинопироксен по составу отвечает авгиту $W_{o_{39-46}} E n_{42-45} F s_{1-14}$, а ортопироксен представлен гиперстеном $E n_{69-74}$ $F S_{22-30} W_{o_{1-4}}$. В отдельных случаях в ортопироксенах зафиксирована слабо проявленная обратная зональность.

Единичные зерна оливина заключенные в реакционную кайму, которые присутствуют в большинстве изученных образцов, имеют состав $\boldsymbol{F o}_{80-88}$. Оливины из меланократового включения по составу варьируют от $\boldsymbol{F o}_{92-88}$ в ядрах до $\boldsymbol{F o}_{88-83}$ в краевых зонах кристаллов. Содержания кальция в таких оливинах составляет 0.073-0.15 мас. \%, что исключает из рассмотрения гипотезу их происхождения за счет дезинтеграции оливинсодержа- 
щих ксенолитов. По данным [Bryant et al., 2007] содержание этого компонента в оливинах мантийных ксенолитов составляет 0.01-0.03 мас. \%.

Интерстициальные стекла продуктов извержений современного экструзивного купола по составу отвечают риолитам $\left(\mathrm{SiO}_{2} \sim 74-80\right.$ мас. \%). Такой интервал вариаций содержания кремнекислоты выдержан в большинстве изученных образцов, вне зависимости от периода извержения (рис. 8a). На графике $\mathrm{SiO}_{2}-\mathrm{K}_{2} \mathrm{O}$ большинство точек составов интерстициальных стекол образуют единый протяженный тренд (см. рис. 8б), который перекрывается с полем составов расплавных включений $\left(\mathrm{SiO}_{2} \sim 69-79\right.$ мас. \%) по данным [Humphreys et al., 2008]. Немногочисленные точки составов интерстициальных стекол и расплавных включений отклоняются от общего тренда и в большей степени обогащены калием.

Петрохимия пород. По химическому составу продукты извержений вулкана в 2001-2013 гг. (табл. 3, рис. 9) за редким исключением относятся к известково-щелочным умеренно-калиевым андезитам $\left(\mathrm{SiO}_{2}=60.5-64.0\right.$ мас. \%; $\mathrm{FeO} * / \mathrm{MgO}=$ $=1.23-1.38 ; \mathrm{K}_{2} \mathrm{O}=1.20-1.42$ мас. \%). Породы имеют высокую магнезиальность $\left(\mathrm{Mg} / \mathrm{Mg}+\mathrm{Fe}^{2+}=\right.$ $=0.56-0.59)$, что типично для пород Молодого Шивелуча [Волынец и др., 1997; Горбач, Портнягин, 2011; Ponomareva et al., 2007].

На рис. 9 показаны вариации главных элементов и выбранных редких элементов в изверженных продуктах 2001-2013 гг. и их сравнение с составами лав и пирокластики, которые характеризуют период деятельности Молодого Шивелуча по данным [Горбач, Портнягин, 2011; Ponomareva et al., 2007]. Точки составов продуктов современных извержений расположены в наиболее кислой части всего спектра пород, изверженных в голоцене. Содержания большинства главных и редких элементов находятся в пределах вариаций, типичных для андезитов Молодого Шивелуча (см. рис. 9). Характерными особенностями андезитов являются низкие содержания $\mathrm{TiO}_{2}, \mathrm{CaO}, \mathrm{FeO}^{*}$ и повышенные содержания $\mathrm{MgO}$ и $\mathrm{Na}_{2} \mathrm{O}$. Породы имеют высокие содержания хрома (до 147 г/т), никеля (до 26 г/т) и стронция (до 633 г/т). Продукты извержений 2001-2013 гг. заметно обеднены калием и барием (см. рис. 9), а также обладают максимально низкими содержаниями иттрия по сравнению с другими породами Молодого Шивелуча с близким содержанием $\mathrm{SiO}_{2}$.

Условия кристаллизации андезитов. Для определения условий кристаллизации андезитов 2001-2013 гг. были использованы термобарометрические уравнения [Ridolfi et al., 2010] и амфибол-плагиоклазовый геотермометр [Holland, Blundy, 1994]. Сопоставление данных, полученных при использовании двух независимых мето-
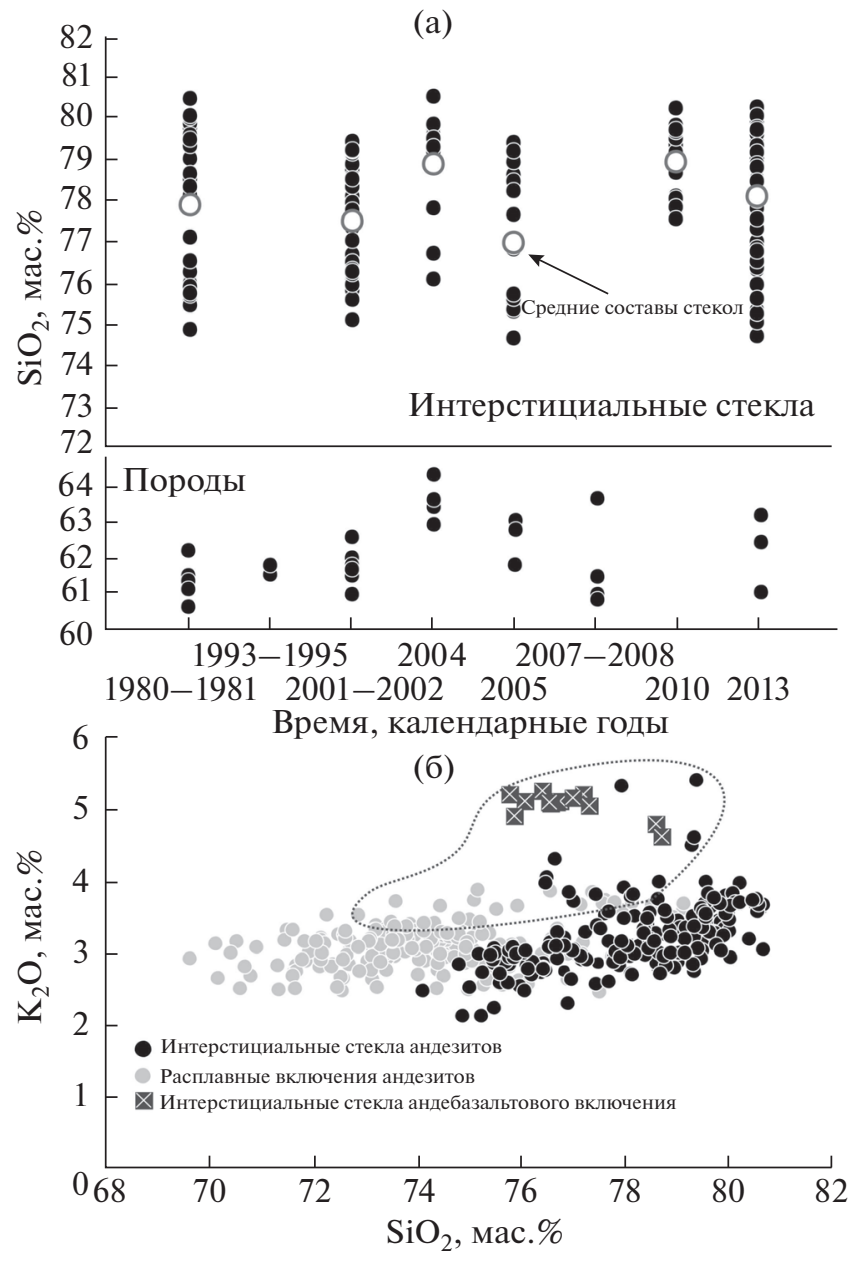

Рис. 8. Состав интерстициальных стекол в породах экструзивного купола.

$\mathrm{a}$ - вариации содержания $\mathrm{SiO}_{2}$ в стеклах во времени (для сравнения также приведены содержания кремнекислоты в породах); б - состав стекол и расплавных включений в координатах $\mathrm{SiO}_{2}-\mathrm{K}_{2} \mathrm{O}$. Составы стекол для продуктов изверженных в 2001, 2005 гг. и 2010 г. по данным работ [Пономарева и др., 2012; Ponomareva et al., 2015]. Составы расплавных включений в плагиоклазах $\mathrm{An}_{29-62}$ и роговой обманке $\mathrm{Mg} \#$ 41-75 заимствованы из работы [Humphreys et al., 2008]. Составы андезитов ранних этапов формирования купола в 1980-1981 и 1993-1995 гг. приведены по данным работ [Иванов, 2008; Толстых и др., 1998]

дов, показывает удовлетворительную сходимость расхождения между определениями в большинстве случаев не превышают погрешностей методов (рис. 10). Средняя температура кристаллизации преобладающей в андезитах современного экструзивного купола минеральной ассоциации магнезиальной роговой обманки и плагиоклаза $A n_{40-50}$ составляет $847 \pm 18^{\circ} \mathrm{C}(n=93)$. Давление, рассчитанное по [Ridolfi et al., 2010], оценивается в 140-150 МПа, что соответствует верхнекоровым условиям и глубине $\sim 5$ км. Эти параметры обнаруживают сходство с данными из работ 


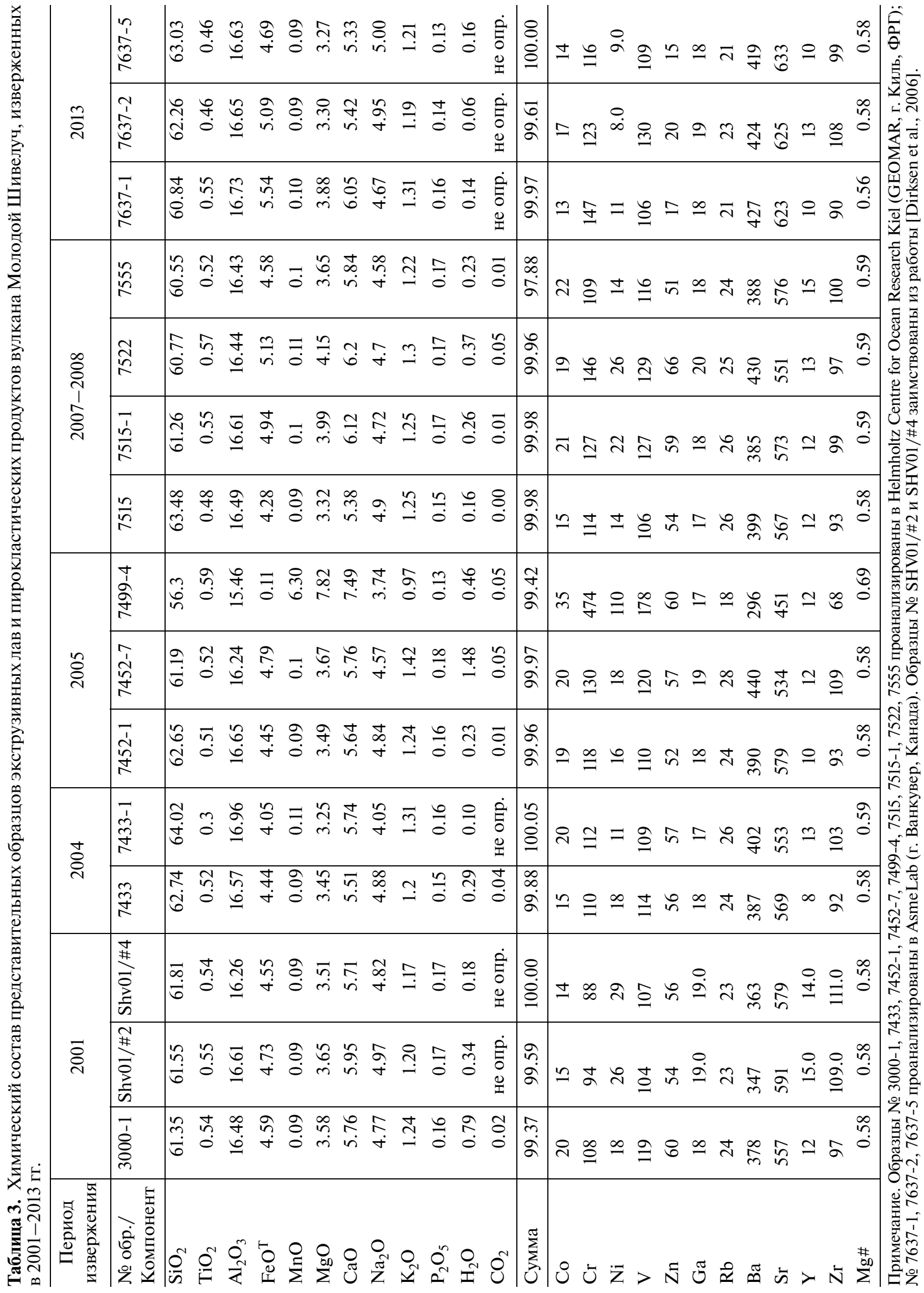



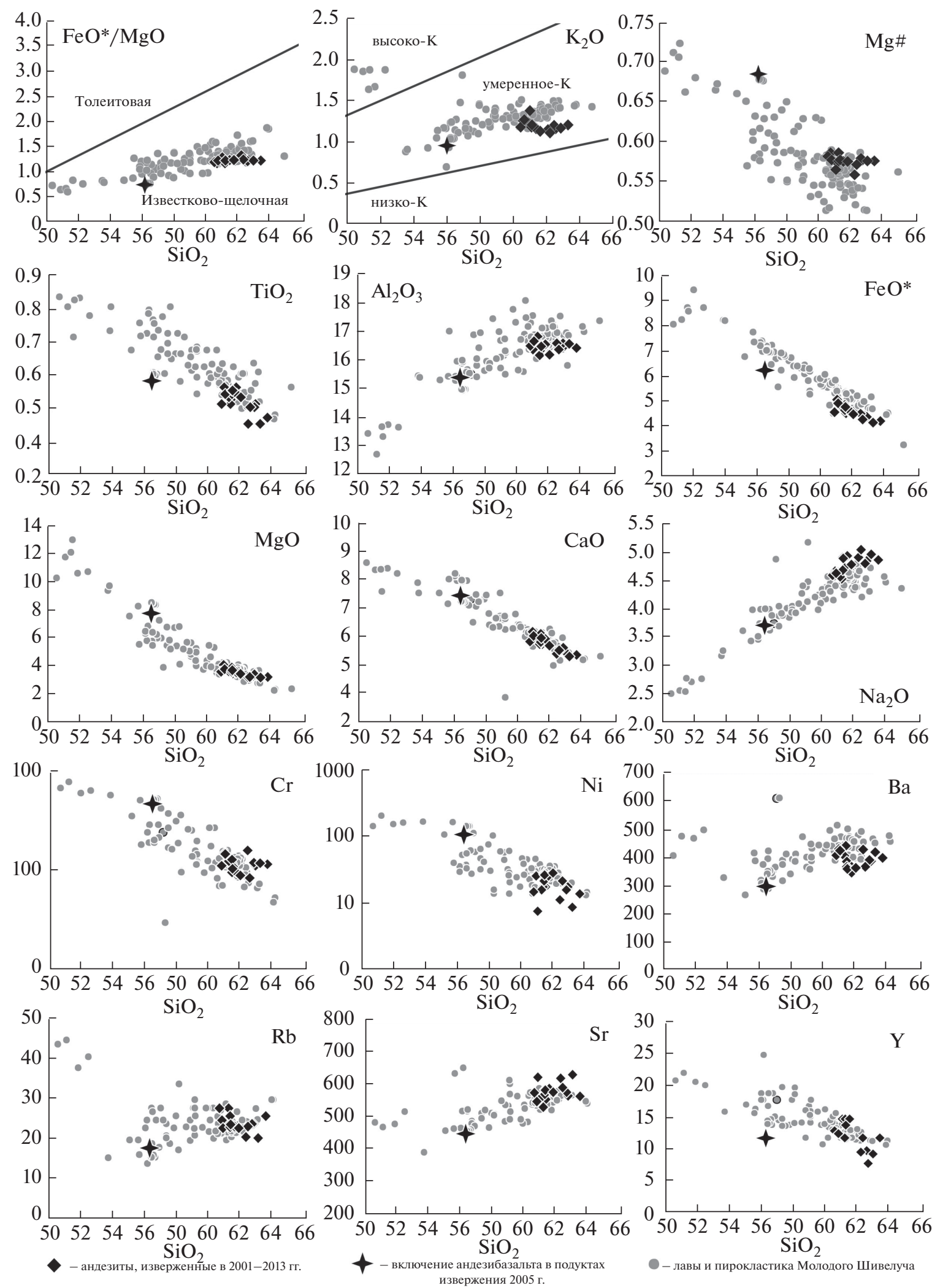

Рис. 9. Вариации $\mathrm{FeO}^{*} / \mathrm{MgO}, \mathrm{Mg} \#\left(=100 \mathrm{Mg} /\left(\mathrm{Mg}+\mathrm{Fe}^{*}\right)\right.$, а также содержаний главных и отдельных редких элементов в андезитах экструзивного купола в зависимости от $\mathrm{SiO}_{2}$.

Содержания главных элементов приведены в мас. \%, редких элементов - в г/т. Составы лав и пирокластики Молодого Шивелуча приведены по данным [Горбач, Портнягин, 2011; Ponomareva et al, 2007]. 


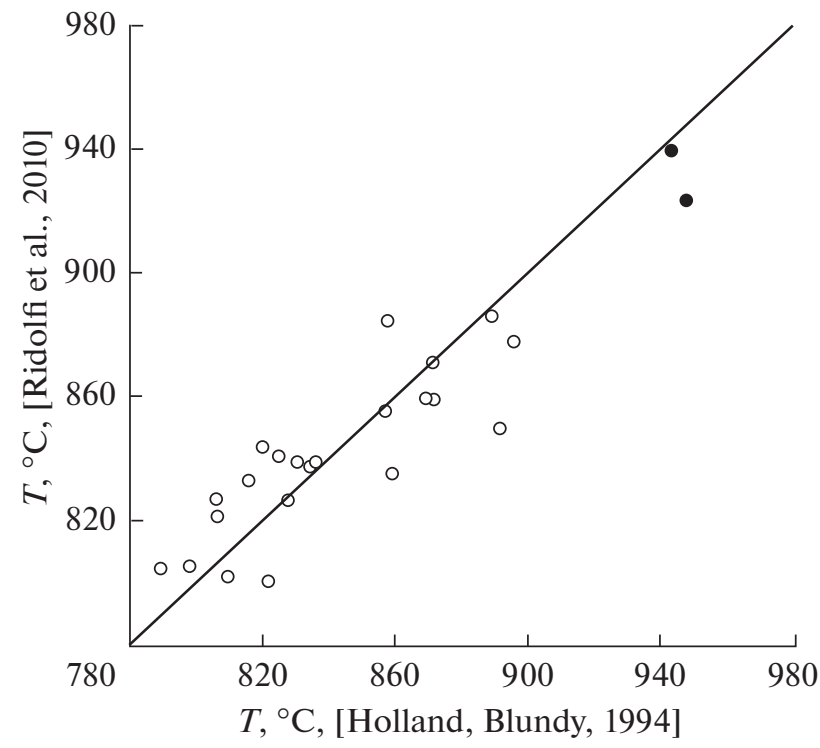

Рис. 10. Температура кристаллизации андезитов современного экструзивного купола по данным двух независимых методов [Holland, Blundy, 1994] и [Ridolfi et al., 2010].

Погрешность при расчете составляет $\pm 35-40^{\circ} \mathrm{C}$ по [Holland, Blundy, 1994] и $\pm 22^{\circ} \mathrm{C}$ по [Ridolfi et al., 2010]. Незалитые кружки отвечают составам преобладающей в андезитах экструзивного купола минеральной ассоциации плагиоклаза $\mathrm{An}_{40-50}$ и магнезиальной роговой обманки с содержанием $\mathrm{Al}_{2} \mathrm{O}_{3}=9-10.5$ мас. \%; залитые кружки соответствуют ассоциации $\mathrm{An}_{65-68}$ и роговой обманке с содержанием $\mathrm{Al}_{2} \mathrm{O}_{3}=11-12$ мас. \%.

[Dirksen et al., 2006; Humhpreys et al., 2006]. Однако, для отдельных генераций кристаллов амфибола с высоким содержанием глинозема, промежуточных зон вкрапленников со сложной зональностью, а в некоторых случаях и для микролитов, получены иные расчетные условия. Средняя температура кристаллизации таких амфиболов составляет $917^{\circ} \pm 23^{\circ} \mathrm{C}(n=38)$, а максимальное рассчитанное значение достигает $970^{\circ} \mathrm{C}$.

\section{ОБСУЖДЕНИЕ РЕЗУЛЬТАТОВ}

Динамика экструзивного процесса. На основании различий в динамике роста экструзивного купола можно выделить два этапа. Первый этап включает извержения 1980-1981 и 1993-1995 гг. и характеризуется прерывистым поступлением экструзивной лавы и меньшей интенсивностью эксплозивной деятельности. В этот период происходит только одно пароксизмальное эксплозивное событие, а экструзия растет за счет выжимания жестких блоков и обелисков и сохраняет куполовидную морфологию с хорошо выраженной короной и осыпной агломератовой мантией. Продукты извержения данного периода имеют выдержанный валовый состав и по опубликованным данным [Толстых и др., 1998; Иванов, 2008] не отличаются резкой гетерогенностью состава породообразующих минералов. Общий объем экструзивной лавы, поступивший в этот период, составляет $0.2 \mathrm{KM}^{3}$.

Второй этап начинается в 2001 г. и продолжается по настоящее время. В ходе этого этапа наблюдается практически непрерывный рост купола - кратковременные перерывы экструзивного процесса отмечались только в отдельные периоды 2003 г. и 2006 г. Купол становится сложной гетерофазной экструзией, отдельные секторы которой сформированы порциями лавы различного строения и морфологии, поступившими на поверхность в разное время и с различной скоростью. Даже по приближенной оценке общий расход магмы в течение 2001-2013 гг. в несколько раз превышает объем андезитов, поступивших на поверхность во время ранних этапов роста купола. В это же время сокращаются временные промежутки между пароксизмальными эксплозивными извержениями, связанными с ростом купола, а наиболее крупные из таких извержений значительно разрушают его постройку. Увеличиваются количество, частота и масштабы эксплозивных событий в межпароксизмальный период (см. табл. 1). К примеру, только с 2007 по 2013 гг. произошло около десяти зафиксированных событий с формированием малообъемных пирокластических потоков протяженностью от 6 до 10-12 км.

Временные вариации валового состава пород, интерстициальных стекол и породообразующих минералов. По сравнению с лавами раннего этапа роста купола в 1980-1981 и 1993-1995 гг., по опубликованным данным [Толстых и др., 1998; Иванов, 2008] обладающими выдержанным составом $\left(\mathrm{SiO}_{2}=60-62\right.$ мас. \% $)$, продукты извержений 2001-2013 гг. обнаруживают несколько большие вариации по содержанию кремнекислоты $\left(\mathrm{SiO}_{2}=60.5-64.0\right.$ мас. \%). На рис. 8б видно, что до 2004 г. в последовательных порциях экструзивных лав отмечалась тенденция к небольшому росту $\mathrm{SiO}_{2}$ в продуктах же последующих извержений содержания кремнекислоты варьируют несистематично. K примеру, среди продуктов, изверженных в 2007-2008 и 2013 гг., одновременно присутствуют разности с содержанием $\mathrm{SiO}_{2}$ от 60.8 до 63.0 мас. \% (см. табл. 3). При сравнении химического и количественно-минералогического составов андезитов прослеживается положительная зависимость. Так, лавы, изверженные в 2004 г., обладают наибольшим содержанием $\mathrm{SiO}_{2}$ и наименьшим количеством вкрапленников среди изученных пород [Горбач, 2006]. Такая же тенденция присутствует и в продуктах извержения 2013 г. (см. рис. 5). Наряду с выдержанным по содержанию $\mathrm{SiO}_{2}$ составом интерстициальных сте- 
кол (см. рис. 8а) это указывает, что небольшие вариации валового химического состава андезитов обусловлены различным объемным соотношением вкрапленников и остаточного расплава.

В отличие от состава пород и интерстициальных стекол, не показывающего широких вариаций, состав породообразующих минералов обладает значительной гетерогенностью (см. рис. 6, 7, 8). Минеральная ассоциация, включающая высоко-Al роговую обманку, высоко-Са плагиоклаз, высоко-Mg оливин наряду с кислым плагиоклазом, низко-Al роговой обманкой и интерстициальным стеклом риолитового состава является типичным примером неравновесной ассоциации, например, [Плечов и др., 2008]. Перечисленные особенности согласуются с данными о гибридном происхождении андезитов Молодого Шивелуча [Волынец и др., 1997; Горбач, Портнягин, 2011; Плечов и др., 2005; Толстых и др., 2015; и др.] и отражают присутствие мафического компонента в питающей системе вулкана.

Состав амфиболов как индикатор пополнения магматической камеры. Состав амфиболов является хорошим индикатором таких параметров как температура, давление и летучесть кислорода и широко используется для расшифровки магматических процессов [Johnson and Rutherford, 1989; Holland and Blundy, 1994, Ridolfi et al., 2010; и др.]. Однако, сложная зональность амфиболов, отражающая изменчивость этих параметров, зачастую трудна для интерпретации [Kiss et al., 2014]. Так, сочетание в андезитах высоко- и низко-Al амфиболов достаточно типично и зафиксировано в породах вулканов Пинатубо, Мерапи, Унзен, МонПеле, Суфриер-Хилл (о. Монсеррат) [Murphy et al., 2000; Pichavant et al., 2002; Pallister et al.,1996; Sato et al., 1999; и др.] и ряда других активных андезитовых вулканов. Такое сочетание наиболее часто интерпретируется как свидетельство существования нескольких уровней накопления и кристаллизации магм и/или процесс смешения разноглубинных магм. Высоко-Al амфиболы рассматриваются как продукты кристаллизации более высокотемпературных глубинных магм, низко$\mathrm{Al}$ - как менее глубинные и низкотемпературные, что соответствует результатам экспериментальных работ. В случае сложной зональности амфибола, когда низко-Al ядро обрастает высоко-Al зоной или каймой, или же присутствует ритмичная или пятнистая зональность, трудно определить, изменение какого параметра играло ключевую роль. Для более точной интерпретации сложной зональности важна позиция конкретного кристалла амфибола в образце. К примеру, в продуктах извержения 26 июля 2013 г. высоко-Al амфиболы присутствуют в виде субфенокристаллов и микролитов с признаками быстрого роста (см. рис. 8). Очевидно, что такие амфиболы были связаны с последними этапами кристаллизации непосредственно перед извержением и не могли кристаллизоваться на глубинных уровнях. В работе [Kiss et al., 2014] показано, что наиболее отчетливо изменение физико-химических условий при кристаллизации амфиболов отражается на двух компонентах химического состава - тетраэдрического алюминия $\left(\mathrm{Al}^{\mathrm{IV}}\right)$ и величины магнезиальности (Mg\#). На графике $\mathrm{Al}^{\mathrm{IV}}-\mathrm{Mg \#}$ (рис. 11) видно, что составы амфиболов андезитов 20012013 гг. подразделяются на три отчетливых тренда по [Kiss et al., 2014]. Тренды отрицательной корреляции $\mathrm{Al}^{\mathrm{IV}}$ и $\mathrm{Mg \#}$ соответствуют изменению температуры и давления при различной величине летучести кислорода. Часть точек составов амфиболов образует тренд положительной корреляции, что по [Kiss et al., 2014] отвечает процессу пополнения магматической камеры новой магмой.

Конвекция в малоглубинной магматической камере. Формирование современного экструзивного купола вулкана Молодой Шивелуч связано с малоглубинной магматической камерой [Горбач, Портнягин, 2011; Dirksen et al., 2006; Humpheys et al., 2006]. На основе расчета скорости формирования реакционной каймы вокруг оливина в работе [Dirksen et al., 2006] высказано предположение, что новая порция мафической магмы могла поступить в малоглубинную магматическую камеру перед извержением 2001 г. - в период от двух месяцев до четырех лет. Данные по составу амфиболов, полученные в этой работе, не противоречат подобному выводу и указывают на то, что часть кристаллов амфибола андезитов, изверженных в 2001-2013 гг., кристаллизовалась из более горячей магмы.

Поступление мафической магмы в нижние горизонты малоглубинной магматической камеры должно привести к формированию разогретого пограничного слоя и к конвективным процессам в основном ее объеме [Плечов и др., 2008; Couch et al., 2001; Sparks, 1977; и др.]. Конвектирующая магма может иметь широкий спектр условий в отношении температуры и давления, содержания кристаллов и концентрации летучих компонентов. Порции горячей магмы, поднимающиеся к верхней части камеры, будут испытывать охлаждение и снижение давления; движение магмы по латерали, в сторону стенок камеры, будет приводить к обильной кристаллизации в условиях снижения температуры и постоянного давления. Нисходящее движение магмы может привести к увеличению давления и температуры, и, следовательно, к резорбции раннее выделившихся кристаллов. В результате конвективных процессов на поверхность могут подниматься порции магмы, сильно неоднородные по содержанию кристаллов, количеству растворенных летучих компонентов и несущие кристаллы с различной термальной историей [Couch et al., 2001]. Избыточ- 


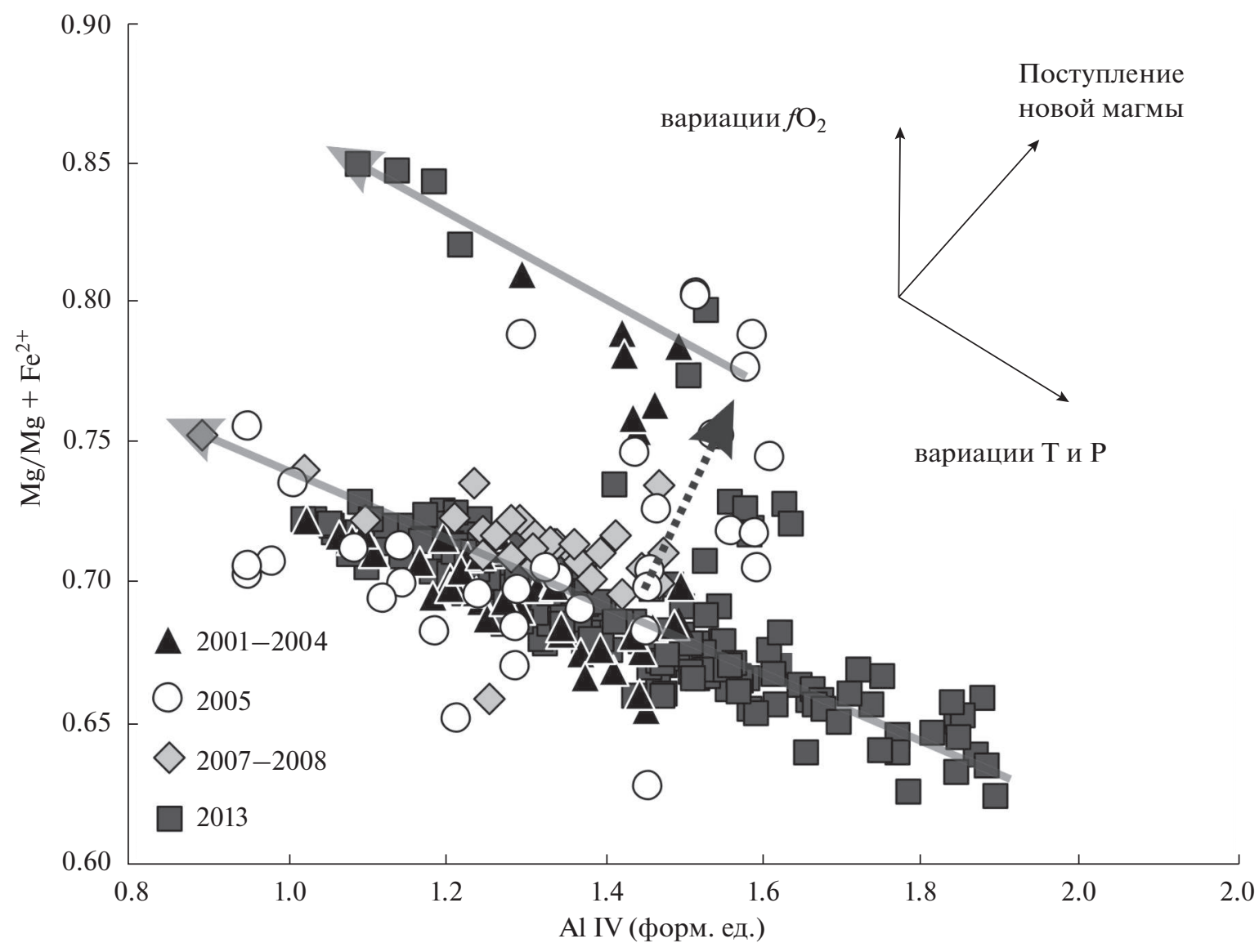

Рис. 11. Вариации магнезиальности $\mathrm{Mg} \#\left(=\mathrm{Mg} /\left(\mathrm{Mg}+\mathrm{Fe}^{2+}\right)\right.$ вкрапленников роговой обманки в андезитах 2001-2013 гг. относительно алюминия в тетраэдрической позиции $\left(\mathrm{Al}^{\mathrm{IV}}\right)$. Тренды, определяющие вариации температуры (T), давления $(\mathrm{P})$ и летучести кислорода $\left(f_{\mathrm{O}_{2}}\right)$, а также отвечающие процессу пополнения магматической камеры новой магмой показаны согласно [Kiss et al., 2014].

ное давление в магматической камере вследствие поступления порции мафической магмы и интенсивного выделения летучих компонентов, которое сопровождает ее кристаллизацию, может привести к увеличению общего расхода магмы, скорости ее поступления на поверхность и роста количества эксплозивных событий.

Такие особенности андезитов Молодого Шивелуча, изверженных в 2001-2013 гг., как гетерогенность минералов по химическому составу и условиям кристаллизации при выдержанном составе интерстициальных стекол и небольших вариациях валового состава пород, хорошо согласуются с механизмом конвективного смешения. Предполагается следующая последовательность процессов в малоглубинной магматической камере вулкана: ее частичное опустошение (1964 г.) - этап кристаллизации и дегазации магмы, сопровождающийся увеличением объема и давления в магматической камере $\rightarrow$ начало роста купола (1980-1981 и
1993-1995 гг.) - этап пополнения и конвекции (2001 г.) $\rightarrow$ усиление эксплозивной деятельности и увеличение расхода экструзивной лавы (2001 г.--настоящее время).

\section{ЗАКЛЮЧЕНИЕ}

В 2001-2013 гг. наблюдался практически непрерывный рост экструзивного купола вулкана Молодой Шивелуч. Характерными особенностями формирования экструзии в этот период являются увеличение общего расхода магмы и рост числа эксплозивных событий. Объем экструзивных лав и пирокластических продуктов, поступивших на поверхность в этот период, в несколько раз превышает объем лав ранних этапов формирования купола в 1980-1981 и 1993-1994 гг. и приближается к $0.9 \mathrm{KM}^{3}$.

Экструзивные лавы и их обломки в отложениях пирокластических потоков, изверженные с 
2001 по 2013 гг., неоднородны по степени кристалличности (от 15 до 45 об. \% вкрапленников) и по содержанию кремнекислоты (от 60.5 до 64.0 мас. \%). Состав интерстициальных стекол андезитов изменяется по содержанию кремнекислоты от 74 до 80 мас. \% и обнаруживает слабую гетерогенность по калию.

Вкрапленники амфибола и плагиоклаза андезитов гетерогенны по составу и условиям кристаллизации. Преобладающая минеральная ассоциация магнезиальной роговой обманки и плагиоклаза кристаллизовалась при температуре $847 \pm 18^{\circ} \mathrm{C}$ и давлении $\sim 140-150$ МПа, что соответствует глубине $\sim 5$ км. Часть вкрапленников амфибола кристаллизовалась при более высокотемпературных условиях $\left(T_{\mathrm{cp}}=917^{\circ} \pm 23^{\circ} \mathrm{C}, T_{\text {мах. }}=\right.$ $=970^{\circ} \mathrm{C}$ ). Перечисленные свойства лав отражают неоднородность поднимающейся магмы и интерпретируются как следствие конвективных процессов в малоглубинной магматической камере.

Авторы благодарны Р.Н. Сагитовой, И.И. Тембрелу, А.В. Сокоренко и А.А. Ножикову за огромную помощь в полевых работах; С.А. Хубуная за предоставленные образцы андезитов, изверженных в 2001 г.; М.Е. Зеленскому за участие в отдельных этапах полевых работ и помощь в получении количественно-минералогических данных на сканирующем электронном микроскопе в ИЭМ РАН.

Полевые исследования выполнялись при поддержке грантов ДВО РАН № 07-III-Д-08-095; 09-III-A-08-422, РФФИ-ДВО РАН № 11-0598555 р_восток_а; завершающий этап работы был выполнен при поддержке гранта РФФИ № 15-0506440 .

\section{СПИСОК ЛИТЕРАТУРЫ}

Белоусов А.Б., Белоусова М.Г. Извержение вулкана Шивелуч в 1964 г. (Камчатка) - плинианское извержение, предварявшееся крупномасштабным обрушением постройки // Вулканология и сейсмология. 1995. № 4/5. С. 116-126.

Волынеи О.Н., Пономарева В.В., Бабанский А.Д. Магнезиальные базальты андезитового вулкана Шивелуч // Петрология. 1997. Т. 5. № 2. С. 206-221.

Гирина О.А., Демянчук Ю.В., Мельников Д.В. и др. Пароксизмальная фаза извержения вулкана Молодой Шивелуч, Камчатка, 27 февраля 2005 г. (предварительное сообщение) // Вулканология и сейсмология. 2006. № 1. C. 16-23.

Гирина О.А., Ушаков С.В., Демянчук Ю.В. Пароксизмальное извержение вулкана Молодой Шивелуч, Камчатка, 9 мая 2004 г. // Вестник КРАУНЦ. Науки о Земле. 2007. Вып. 10. № 2. С. 65-73.

Гирина О.А., Коновалова О.А., Маневич А.Г. и др. Активность вулканов Камчатки в 2009 г. // Современный вулканизм и связанные с ним процессы. Материалы конференции, посвященной Дню вулканолога, Петро-
павловск-Камчатский, 29-30 марта 2010 г. Петропавловск-Камчатский: ИВиС ДВО РАН, 2011. С. 41-49.

Гирина О.А., Маневич А.Г., Мельников Д.В. и др. Активность вулканов Камчатки в 2011 г. // Вулканизм и связанные с ним процессы. Материалы региональной научной конференции, посвященной Дню вулканолога. Петропавловск-Камчатский, 29-30 марта 2012 г. Петропавловск-Камчатский: ИВиС ДВО РАН, 2012. C. 28-33.

Гирина О.А., Нуждаев А.А. О некоторых особенностях извержения вулкана Молодой Шивелуч, Камчатка, 22 сентября 2005 г. // Вулканология и сейсмология 2014a. № 4. C. 20-30.

Гирина О.А., Маневич А.Г., Мельников Д.В. и др. Активность вулканов Камчатки в 2013 г. // Вулканизм и связанные с ним процессы. Материалы региональной научной конференции, посвященной Дню вулканолога, 27-28 марта 2014 г. Петропавловск-Камчатский: ИВиС ДВО РАН, 2014б. С. 38-45.

Горбач Н.В. Первый лавовый поток на экструзивном куполе вулкана Шивелуч, 2004 г. // Вулканология и сейсмология. 2006. № 2. С. 9-16.

Горбач Н.В., Портнягин М.В. Геологическое строение и петрология лавового комплекса вулкана Молодой Шивелуч // Петрология. 2011. Т. 19. № 2. С. 140-172.

Горбач Н.В., Плечова А.А., Пономарева В.В., Тембрел И.И. Эксплозивное извержение вулкана Шивелуч 26 июля 2013 г. // Вестник КРАУНЦ. Науки о Земле. 2013. Вып. 22. № 2. С. 15-19.

Горельчик В.И., Гарбузова В.Т., Дрознин Д.В. и др. Вулкан Шивелуч: глубинное строение и прогноз извержения по данным детальной сейсмичности 1962-1994 гг. // Вулканология и сейсмология. 1995. № 4/5. С. 54-76.

Горшков Г.С. Дубик Ю.М. Направленный взрыв на вулкане Шивелуч // Вулканы и извержения. М.: Наука, 1969. C. 3-38.

Двигало В.Н. Рост купола в кратере вулкана Шивелуч в 1980-1981 гг. по фотограмметрическим данным // Вулканология и сейсмология. 1984. № 2. С. 104-109.

Двигало В.Н., Свирид И.Ю., Шевченко А.В. и др. Состояние активных вулканов Северной Камчатки по данным аэрофотосъемочных облетов и фотограмметрической обработки снимков 2010 г. // Вулканизм и связанные с ним процессы. Материалы региональной конференции, посвященной Дню вулканолога, 30 марта-1 апреля 2011 г. Петропавловск-Камчатский: ИВиС ДВО РАН, 2011. С. 26-36.

Иванов Б.В., Чирков А.М., Дубик Ю.М. и др. Состояние вулканов Камчатки и Курильских островов в 1980 г. // Вулканология и сейсмология. 1981. № 3. С. 99-104.

Иванов Б.В. Андезиты Камчатки. Справочник химических анализов вулканитов и основных породообразующих минералов. М.: Наука, 2008. 364 с.

Жаринов Н.А., Богоявленская Г.Е., Хубуная С.А. и др. Новый эруптивный цикл вулкана Шивелуч - 19801993 гг. // Вулканология и сейсмология. 1995. № 1. C. 20-29.

Жаринов Н.А., Демянчук Ю.В. Рост экструзивного купола вулкана Шивелуч (Камчатка) в 1980-2007 гг. по геодезическим данным и видеосъемке // Вулканология и сейсмология. 2008. № 4. С. 3-14. 
Жаринов Н.А., Демянчук Ю.В. Крупные эксплозивные извержения вулкана Шивелуч (Камчатка) с частичным разрушением экструзивного купола 28 февраля 2005 г. и 27 октября 2010 г. // Вулканология и сейсмология. 2013. № 3. С. 48-62.

Маневич А.Г., Гирина О.А., Мельников Д.В. и др. Активность вулканов Камчатки и о. Парамушир Северных Курил в 2008 г. // Материалы конференции, посвященной Дню вулканолога, Петропавловск-Камчатский, 30-31 марта 2009 г. Петропавловск-Камчатский: ИВиС ДВО РАН, 2010. С. 7-14.

Мелекесиев И.В., Волынеи, О.Н., Ермаков В.А. и др. Вулкан Шивелуч // Действующие вулканы Камчатки. Т. 1. М.: Наука, 1991. С. 84-103.

Мелекесиев И.В., Двигало В.Н., Кирсанова Т.П. и др. 300 лет жизни камчатских вулканов: Молодой Шивелуч (анализ динамики и последствий эруптивной активности в XVII-XX вв.) Часть II. 1965-2000 гг. // Вулканология и сейсмология. 2004. № 1. С. 3-20.

Нуждаев А.А., Гирина О.А, Мельников Д.В. Некоторые результаты изучения пирокластических отложений извержений 28 февраля и 22 сентября 2005 г. вулкана Молодой Шивелуч наземными и дистанционными методами // Вестник КРАУНЦ. Науки о Земле. 2005. Вып. 6. № 2. С. 62-66.

Озеров А.Ю., Демянчук Ю.В. Пароксизмальное извержение вулкана Молодой Шивелуч 10 мая 2004 г. // Вулканология и сейсмология. 2004. № 5. С. 75-80.

Пономарева В.В., Портнягин М.В., Мельников Д.В. Состав тефры современных (2009-2011 гг.) извержений вулканов Камчатки и Курильских островов // Вестник КРАУНЦ. Науки о Земле. 2012. Вып. 20. № 2. С. 7-21.

Плечов П.Ю., Пузанков М.Ю., Дирксен О.В., Латышев Н.П. Причины роста экструзивного купола вулкана Шивелуч // Происхождение магматических пород. Материалы международного (Х всероссийского) петрографического совещания. Апатиты, 2005. 304 с.

Плечов П.Ю., Фомин И.С., Мельник О.Э. и др. Эволюция состава расплава при внедрении базальтов в кислый магматический очаг // Вестник МГУ. Cер. IV. Геология. 2008. № 4. С. 35-44.

Толстых М.Л., Наумов Б.В., Бабанский А.Д. и др. Состав расплава и условия кристаллизации андезитов вулкана Шивелуч, Камчатка (по данным изучения расплавов в минералах) // ДАН. 1998. Т. 359. № 5. С. 676-679.

Толстых М.Л., Певзнер М.М., Наумов В.Б. и др. Типы расплавов, формировавших пирокластические породы различных структурно-возрастных комплексов вулканического массива Шивелуч (Камчатка) по данным изучения включений в минералах // Петрология. 2015. T. 23. № 4. C. 1-40.

Федотов С.А., Двигало В.Н., Жаринов Н.А. и др. Извержение вулкана Шивелуч в мае-июле 2001 г. // Вулканология и сейсмология. 2001. № 6. С. 1-13.

Федотов С.А., Двигало В.Н., Жаринов Н.А. и др. Эруптивный цикл вулкана Шивелуч в 2001-2004 гг. // Вулканология и сейсмология. 2004. № 6. С. 1-12.

Федотов С.А., Хубуная С.А., Жаринов Н.А. и др. Извержение вулканов Шивелуч и Ключевской в 1993 г. и их влияние на окружающую среду // Геология и геофизика. 1995. № 8. С. 117-131.
Хубуная С.А., Жаринов Н.А., Муравьев Я.Д. и др. Извержение вулкана Шивелуч в 1993 г. // Вулканология и сейсмология. 1995. № 1. С. 3-20.

Шевченко А.В., Свирид И.Ю., Двигало В.Н. Современная экструзивная деятельность вулкана Молодой Шивелуч по данным геоморфологического дешифрирования и фотограмметрической обработки стереофотоснимков // Вестник КРАУНЦ. Науки о Земле. 2014. Вып. 24. № 2. С. 147-159.

Bryant J.A., Yogodzinski G.M., Churikova T.G. Melt-mantle interaction beneath Kamchatka arc evidence from ultramafic xenoliths from Shiveluch volcano // Geochemistry, Geophysics, Geosystems. 2007. V. 4. № 8. P. 1-24.

Couch S., Sparks R.S.J., Carroll M.R. Mineral disequilibrium in lavas explained by convective self-mixing in open magma chambers // Nature. 2001. V. 411. P. 1037-1039.

Dirksen O., Humphreys M.C.S., Pletchov P. et al. The 20012004 dome-forming eruption of Shiveluch Volcano, Kamchatka: observation, petrological investigation and numerical modeling // Journal of Volcanology and Geothermal Research. 2006. V. 155. P. 201-226.

Jarosewich E.J., Nelen J.A., Norberg J.A. Reference samples for electron microprobe analysis // Geostandards Newsletter. 1980. V. 4. P. 43-47.

Gorbach N.V. New lava of Shiveluch volcano: en evidense of magma mingling? // 5rd Biennial Workshop on Subduction Processes emphasizing the Japan-Kurile-Kamchatka-Aleutian Arcs (JKASP_5). Japan, July 9-14, 2006. P. 133-137.

Holland T., Blundy J.D. Non-ideal interactions in calcic amphiboles and their bearing on amphibole-plagioclase thermometry // Contributions to Mineralogy and Petrology. 1994. V. 116. P. 433-447.

Humphreys M.C.S., Blundy J.D., Sparks R.S.J. Magma Evolution and Open-System Processes at Shiveluch Volcano: Insights from Phenocryst Zoning // Journal of Petrology. 2006. V. 47. № 12. P. 2303-2334.

Humphreys M.C.S., Blundy J.D., Sparks R.S.J. Shallow-level decompression crystallisation and deep magma supply at Shiveluch Volcano // Contributions to Mineralogy and Petrology. 2008. V. 155. P. 45-61.

Johnson M.C., Rutherford M.J. Experimental calibration of the aluminum-in-hornblende geobarometer with application to Long Valley caldera (California) volcanic rocks // Geology. 1989. V. 17. № 9. P. 837-841.

Kiss B., Harangi S., Ntaflos T. et al. Amphibole perspective to unravel pre-eruptive processes and conditions in volcanic plumbing systems beneath intermediate arc volcanoes: a case study from Ciomadul volcano (SE Carpathians) // Contribution of Mineralogy and Petrology. 2014. V. 167. P. 986.

Leake B.E., Woolley A.R., Arps C.E.S. et al. Nomenclature of ampfhiboles: Report of the Subcommittee on Amphiboles of the Mineralogical Association // Mineralogical Magazine. 1997. V. 61. № 3. P. 295-321.

Murphy M.D., Sparks R.S.J., Barclay J. et al. Remobilization of Andesite Magma by Intrusion of Mafic Magma at the Soufriere Hills Volcano, Montserrat, West Indies // Journal of Petrology. 2000. V. 41. № 1. P. 21-42.

Pallister J. S., Hoblitt R.P., Meeker G.P. et al. Magma mixing at Mount Pinatubo: petrographic and chemical evidence from the 1991 deposits // Fire and Mud: Eruptions and Lahars of Mount Pinatubo / Eds Newhall C.G, 
Punongbayan R.S. Philippines. University of Washington Press. Seattle, 1996. P. 687-731.

Ponomareva V.V., Kyle P., Pevzner M.M. et al. Holocene Eruptive History of Shiveluch Volcano, Kamchatka Peninsula, Russia // Volcanism and Subduction: The Kamchatka region / Eds Eichelberger J., Gordeev E., Izbekov P., Lees J. AGU Geophysical Monograph. 2007. V. 172. P. 263-282.

Ponomareva V., Portnyagin M., Pevzner M. et al. Tephra from andesitic Shiveluch volcano, Kamchatka, NW Pacific: Chronology of explosive eruptions and geochemical fingerprinting of volcanic glass // International Journal of Earth Sciences. 2015. V. 104. P. 1459-1482.

Ridolfi F., Renzulli A., Puerini M. Stability and chemical equilibrium of amphibole in calc-alkaline magmas: an overview, new thermobarometric formulations and application to subduction-related volcanoes // Contributions to Mineralogy and Petrology. 2010. V. 160. P. 45-66.

Sato H., Nakada S., Fujii T. et al. Groundmass pargasite in the 1991-1995 dacite of Unzen volcano: phase stability experiments and volcanological implications // Journal of Volcanology and Geothermal Research. 1999. V. 89. № 1/4. P. 197-212.

Shevchenko A.V., Dvigalo V.N., Svirid I.Y. Airborne photogrammetry and geomorphological analysis of the 20012012 exogenous dome growth at Molodoy Shiveluch Volcano, Kamchatka // Journal of Volcanology and Geothermal Research. 2015. V. 304. P. 94-107.

Sparks R.S.J., Sigurdsson H., Wilson L. Magma mixingmechanism for triggering acid explosive eruptions // Nature. 1977. V. 267. P. 315-318. 